\title{
Optimization of Cowpea Dry Grain Yield through the Stimulation of the RNA Synthetic Activity of NADH-Glutamate Dehydrogenase
}

\author{
Godson 0. Osuji1 ${ }^{*}$, Paul M. Johnson1, Wenceslaus C. Madu² \\ ${ }^{1}$ College of Agriculture and Human Sciences, Prairie View A \& M University, Prairie View, Texas, USA \\ ${ }^{2}$ Imo State University of Agriculture and Environmental Sciences, Owerri, Nigeria \\ Email: ^osujigodson99@gmail.com, goosuji@pvamu.edu
}

How to cite this paper: Osuji, G.O., Johnson, P.M. and Madu, W.C. (2021) Optimization of Cowpea Dry Grain Yield through the Stimulation of the RNA Synthetic Activity of NADH-Glutamate Dehydrogenase. American Journal of Plant Sciences, 12, 71-103.

https://doi.org/10.4236/ajps.2021.121006

Received: September 22, 2020

Accepted: January 25, 2021

Published: January 28, 2021

Copyright $\odot 2021$ by author(s) and Scientific Research Publishing Inc. This work is licensed under the Creative Commons Attribution International License (CC BY 4.0).

http://creativecommons.org/licenses/by/4.0/

\begin{abstract}
Several potentially practical biochemical processes in plant systems still remain hidden, especially the NADH-glutamate dehydrogenase (GDH) synthesis of nongenetic code-based RNA that optimizes crop nutritious yield by degrading superfluous genetic code-based RNA. In continued characterization of the biochemistry of cowpea grain yield, GDH was purified by electrophoresis from seeds of cowpea treated with solutions of stoichiometric mixes of mineral salts. The GDH was made to synthesize RNAs in the amination $\left(\alpha-\mathrm{KG} / \mathrm{NADH} / \mathrm{NH}_{4}^{+}\right)$and then in the deamination (L-Glu/NAD ${ }^{+}$) direction. The initial product RNAs were captured and sequenced. The grand challenge was to discover the specific molecular roles of the redox enzyme in the optimization of cowpea grain yields. In the amination direction, the GDH hexamers synthesized plus-RNA, but in the deamination direction, they synthesized minus-RNA. The plus-RNAs and minus-RNAs were homologous to about the same numbers of different mRNAs encoding the key enzymes that regulate photosynthesis; saccharide biochemistry and glycolysis; phenylpropanoid biosynthesis; nodulation nitrogen fixing processes; dehydrin drought and glutathione environmental stress resistance processes; purine, pyrimidine, DNA, RNA and essential amino acid biosynthesis; storage protein vicilin accumulation; isoflavone earliness of cowpea maturity; peroxidase synthesis of lignin and sequestration of $\mathrm{CO}_{2}$ to enrich soil organic carbon contents; triglyceride physiology in the biosynthesis of bioactive compounds that render cowpea resistant to insects and fungi; etc., all of which constitute the GDH chemical pathways for discrimination of biochemical, physiological, metabolic, genetic reactions; and optimization of cowpea dry grain yields. Each stoichiometric mix of mineral salts produced optimally yielding biochemical variant of purple hull cowpea; the $\mathrm{K}+\mathrm{K}+\mathrm{K}$ mix was spectacular because it
\end{abstract}


increased the grain yield to $7598 \mathrm{~kg}$ from the $3644 \mathrm{~kg} \cdot \mathrm{ha}^{-1}$ in the control cowpea. Optimized nutritious staple crop yield buttresses food security. The synthesis of plus-RNA in amination and minus-RNA in deamination is an economic tactical plan in biochemistry for the selection of superfluous mRNAs that would be degraded to assure the survival of cowpea growing under unfavorable environmental conditions.

\section{Keywords}

Stoichiometric Mineral Salt Mixes, Glutamate Dehydrogenase Cycle, Photosynthesis, Nodulation, Vicilin, Double Grain Yields, Food Security

\section{Introduction}

Cowpea (Vigna unguiculata L. Walp) is a primary source of cholesterol-free dietary protein throughout the world; it is an important cover/forage crop; breeding programs have optimized environment-resilient cultivars [1] [2]; and its molecular markers have been characterized [3]. It is not surprising therefore that global production of this important staple crop increased from 1 million tonnes in 1971 to 7 million tonnes in 2014, and the yield (kilogram per hectare) increased from 237 to 614 in the same period [1]. The dry grain yields [4] of genetically improved cultivars are the highest in the USA (1790 kg.ha- ${ }^{-1}$ average) and China $\left(1038 \mathrm{~kg} \cdot \mathrm{ha}^{-1}\right)$, but the lowest in the Sub-Sahara Africa $\left(299 \mathrm{~kg} \cdot \mathrm{ha}{ }^{-1}\right)$. South Asians, Caribbeans, Latin Americans, and Sub-Saharan Africans consume [1] more cowpeas (33g per capita per day) than Europeans (7g per capita per day). New cowpea varieties that are resistant to insect pests, parasitic weeds, nematodes, bacterial pathogens, viruses, and fungal diseases have been released but production constraints in small holder farms remain unsolved [5] [6]. Quantities of atmospheric nitrogen fixed, and $\mathrm{CO}_{2}$ sequestered into the soil by the cover crop in parts of Sub-Sahara Africa are also very low [7] [8]. Therefore, there is the need to improve the dry grain yields of this important nutritious staple crop of the world by applying other biotechnologies to support plant breeding efforts, without cultivation of more land area. Food security is best buttressed by boosting the yields of nutritious staple crops without increasing man-hour inputs. In that way, nutritious food becomes an affordable common commodity.

In the light of the above inexplicably variable yield phenomena, cowpea could possess a complex molecular biology. An aim of this research program was to begin to decipher cowpea molecular biology and to optimize, and maximize the dry grain yield by applying the NADH-glutamate dehydrogenase-based crop nutritious yield doubling biotechnology [9]-[16].

Glutamate dehydrogenase (GDH; EC 1.4.1.2) has a complex chemical reaction mechanism [9]. In the narrow context, it is a redox enzyme catalyzing the reductive amination of $\alpha$-ketoglutarate $(\alpha-K G)$ in the forward direction, and the oxidative deamination of L-glutamate in the reverse direction. In addition, it poly- 
merizes ribonucleoside triphosphates independent of any template to produce nongenetic code-based RNA that degrades total RNA [10]. GDH is easily induced to synthesize RNA by a wide range of environmental factors including soil organic carbon content, cellular intermediary biochemicals, biotic stress factors, mineral ions, drought, temperature extremes, agricultural chemicals, etc. [17] [18] [19].

GDH has a complicated mixture of hexameric isoenzymes with different isoelectric point (pI) values [20] [21] [22] [23]. The RNAs synthesized by the alkaline isoenzymes $(\beta 6)$ have high $\mathrm{A}+\mathrm{T}$ contents, the RNAs synthesized by the acidic isoenzymes ( $a 6$, and $\alpha 6$ ) have high $\mathrm{G}+\mathrm{C}$ contents [21]. It is expected that further understanding of GDH chemical mechanisms will unravel the complex molecular biology of cowpea and lead to the optimization of its dry grain yield.

\section{Materials and Methods}

\subsection{Stimulation of NADH-GDH Activity in Cowpea}

GDH synthesis of RNA was enhanced by treatment of cowpea with stoichiometric mineral salt solutions [16]. Cowpea (Vigna unguiculata purple hull) seeds were planted in $120 \times 120 \times 30 \mathrm{~cm}$ (width $\times$ length $\times$ depth) raised beds, each filled with 3 bags of professional growing mix (Sungro Horticulture, Bellevue, Washington, USA) mixed with 2 bags of organic matter-rich top soil (Landscapers Pride, New Waverly, Texas, USA) to create healthy soil. Each raised bed was placed on level ground in the field on a weed-blocking plastic mat. About 25 seeds were planted per bed in May 2014. There was replanting to make up for the few ungerminated seeds. The applied stoichiometric mineral salt compositions were based on the model molar combinations mimicking the GDH hexameric isoenzymes [11] that rapidly activate the plant's GDH. Twenty eight different stoichiometric mineral salt treatments (Table 1) were used, each one studied in duplicate raised beds to make a total of 56 beds. A liter of stoichiometric mineral salts solution was applied to each bed three times: first at 2 weeks after seed germination, again at flowering stage, and finally at post flowering stage. The commercial fertilizer was $200 \mathrm{~g}$ of triple 15 applied one time to the raised bed at 2 weeks after seed germination. Pods matured in two phases. The early maturing pods were harvested at 8 - 9 weeks when the pods turned yellow; the slow maturing pods were harvested when the cowpea leaves turned yellow. Pods were harvested per bed, manually shelled, dry grain was weighed separately, and the grains were stored at room temperature.

\subsection{Multi-Dimensional Electrophoretic Purification of GDH Hexameric Isoenzymes}

GDH was purified from cowpea seeds ( $30 \mathrm{~g}$ ) harvested from the control or mineral salts-treated raised beds according to Rotofor isoelectric focusing method [23]. The isoelectric focusing ampholyte was Bio-Rad's Bio-Lyte 3/10. Ribonuclease $\mathrm{A}$ ( 1 unit per $\mathrm{ml}$ of the extraction buffer solution), and deoxyribonuclease 1 
Table 1. Dry grain yield of purple hull cowpea $\left(\mathrm{Kg} \cdot \mathrm{Ha}^{-1}\right)$.

\begin{tabular}{|c|c|c|c|}
\hline Stoichiometric Mineral Salt Mixes & Early Harvest & $2^{\text {nd }}$ Harvest & Total yield \\
\hline 1) $\mathrm{K}+\mathrm{K}+\mathrm{K}(12 \mathrm{mM} \mathrm{KCl}$ solution $)$ & $2965 \pm 105$ & $3633 \pm 140$ & $7598 \pm 122$ \\
\hline 2) $\mathrm{N}+\mathrm{N}+\mathrm{P}+\mathrm{K}\left(50 \mathrm{mM} \mathrm{NH}_{4} \mathrm{Cl}\right.$ plus $20 \mathrm{mM} \mathrm{Na}_{2} \mathrm{HPO}_{4}$ plus $4 \mathrm{mM} \mathrm{KCl}$ solution $)$ & $3600 \pm 120$ & $2960 \pm 114$ & $6560 \pm 109$ \\
\hline 3) $\mathrm{S}$ ( $50 \mathrm{mM} \mathrm{Na}_{2} \mathrm{SO}_{4}$ solution $)$ & $4060 \pm 166$ & $1884 \pm 107$ & $5944 \pm 129$ \\
\hline 4) $\mathrm{K}+\mathrm{K}+\mathrm{S}\left(8 \mathrm{mM} \mathrm{KCl}\right.$ plus $50 \mathrm{mM} \mathrm{Na}_{2} \mathrm{SO}_{4}$ solution $)$ & $3297 \pm 213$ & $2556 \pm 90$ & $5853 \pm 150$ \\
\hline 5) $\mathrm{K}+\mathrm{K}(8 \mathrm{mM} \mathrm{KCl}$ solution $)$ & $3755 \pm 101$ & $2018 \pm 80$ & $5773 \pm 83$ \\
\hline 6) $\mathrm{N}+\mathrm{P}+\mathrm{K}\left(25 \mathrm{mM} \mathrm{NH}_{4} \mathrm{Cl}\right.$ plus $20 \mathrm{mM} \mathrm{Na}_{2} \mathrm{HPO}_{4}$ plus $4 \mathrm{mM} \mathrm{KCl}$ solution $)$ & $3191 \pm 130$ & $2556 \pm 81$ & $5748 \pm 121$ \\
\hline 7) $\mathrm{K}+\mathrm{K}+\mathrm{N}\left(8 \mathrm{mM} \mathrm{KCl}\right.$ plus $25 \mathrm{mM} \mathrm{NH}_{4} \mathrm{Cl}$ solution $)$ & $3559 \pm 190$ & $2018 \pm 94$ & $5570 \pm 140$ \\
\hline 8) $\mathrm{P}+\mathrm{P}+\mathrm{K}\left(40 \mathrm{mM} \mathrm{Na}_{2} \mathrm{HPO}_{4}\right.$ plus $4 \mathrm{mM} \mathrm{KCl}$ solution $)$ & $2335 \pm 82$ & $3229 \pm 110$ & $5564 \pm 91$ \\
\hline 9) Regular Fertilizer (triple 15) & $2846 \pm 143$ & $2634 \pm 156$ & $5469 \pm 148$ \\
\hline 10) $\mathrm{K}+\mathrm{N}\left(4 \mathrm{mM} \mathrm{KCl}\right.$ plus $25 \mathrm{mM} \mathrm{NH}_{4} \mathrm{Cl}$ solution $)$ & $3553 \pm 150$ & $1884 \pm 69$ & $5436 \pm 94$ \\
\hline 11) $\mathrm{P}+\mathrm{P}+\mathrm{N}\left(40 \mathrm{mM} \mathrm{Na}_{2} \mathrm{HPO}_{4}\right.$ plus $25 \mathrm{mM} \mathrm{NH}_{4} \mathrm{Cl}$ solution $)$ & $3937 \pm 119$ & $1480 \pm 76$ & $5417 \pm 86$ \\
\hline 12) $\mathrm{P}+\mathrm{K}\left(20 \mathrm{mM} \mathrm{Na}_{2} \mathrm{HPO}_{4}\right.$ plus $4 \mathrm{mM} \mathrm{KCl}$ solution $)$ & $3497 \pm 101$ & $18847 \pm 90$ & $5381 \pm 95$ \\
\hline 13) $\mathrm{K}+\mathrm{K}+\mathrm{P}+\mathrm{S}\left(8 \mathrm{mM} \mathrm{KCl}\right.$ plus $20 \mathrm{mM} \mathrm{Na}_{2} \mathrm{HPO}_{4}$ plus $50 \mathrm{mM} \mathrm{Na}_{2} \mathrm{SO}_{4}$ solution) & $3455 \pm 120$ & $17496 \pm 220$ & $5204 \pm 194$ \\
\hline 14) $\mathrm{P}+\mathrm{N}\left(20 \mathrm{mM} \mathrm{Na}_{2} \mathrm{HPO}_{4}\right.$ plus $25 \mathrm{mM} \mathrm{NH}_{4} \mathrm{Cl}$ solution $)$ & $2363 \pm 120$ & $2691 \pm 109$ & $5054 \pm 112$ \\
\hline 15) $\mathrm{N}+\mathrm{N}+\mathrm{S}\left(50 \mathrm{mM} \mathrm{NH}_{4} \mathrm{Cl}\right.$ plus $50 \mathrm{mM} \mathrm{Na}_{2} \mathrm{SO}_{4}$ solution $)$ & $3759 \pm 109$ & $1211 \pm 63$ & $4970 \pm 95$ \\
\hline 16) $\mathrm{N}+\mathrm{P}+\mathrm{K}+\mathrm{S}\left(25 \mathrm{mM} \mathrm{NH}_{4} \mathrm{Cl}\right.$ plus $20 \mathrm{mM} \mathrm{Na}_{2} \mathrm{HPO}_{4}$ plus $4 \mathrm{mM} \mathrm{KCl}$ plus $50 \mathrm{mM} \mathrm{Na}_{2} \mathrm{SO}_{4}$ solution $)$ & $3551 \pm 103$ & $1345 \pm 66$ & $4897 \pm 81$ \\
\hline 17) $\mathrm{P}+\mathrm{K}+\mathrm{S}\left(20 \mathrm{mM} \mathrm{Na}_{2} \mathrm{HPO}_{4}\right.$ plus $4 \mathrm{mM} \mathrm{KCl}$ plus $50 \mathrm{mM} \mathrm{Na}_{2} \mathrm{SO}_{4}$ solution $)$ & $2998 \pm 78$ & $1884 \pm 69$ & $4882 \pm 71$ \\
\hline 18) $\mathrm{K}(4 \mathrm{mM} \mathrm{KCl}$ solution) & $3621 \pm 61$ & $1211 \pm 59$ & $4832 \pm 58$ \\
\hline 19) $\mathrm{N}+\mathrm{P}+\mathrm{K}+\mathrm{K}\left(25 \mathrm{mM} \mathrm{NH}_{4} \mathrm{Cl}\right.$ plus $20 \mathrm{mM} \mathrm{Na}_{2} \mathrm{HPO}_{4}$ plus $8 \mathrm{mM} \mathrm{KCl}$ solution $)$ & $2295 \pm 30$ & $2287 \pm 80$ & $4583 \pm 61$ \\
\hline 20) $\mathrm{K}+\mathrm{K}+\mathrm{P}\left(8 \mathrm{mM} \mathrm{KCl}\right.$ plus $40 \mathrm{mM} \mathrm{Na}_{2} \mathrm{HPO}_{4}$ solution $)$ & $3085 \pm 88$ & $1345 \pm 89$ & $4431 \pm 87$ \\
\hline 21) $\mathrm{K}+\mathrm{S}\left(4 \mathrm{mM} \mathrm{KCl}\right.$ plus $50 \mathrm{mM} \mathrm{Na}_{2} \mathrm{SO}_{4}$ solution $)$ & $3331 \pm 94$ & $1076 \pm 52$ & $4407 \pm 70$ \\
\hline 22) $\mathrm{P}\left(20 \mathrm{mM} \mathrm{Na}_{2} \mathrm{HPO}_{4}\right.$ solution $)$ & $3162 \pm 35$ & $1076 \pm 47$ & $4238 \pm 41$ \\
\hline 23) $\mathrm{N}+\mathrm{N}\left(50 \mathrm{mM} \mathrm{NH}_{4} \mathrm{Cl}\right.$ solution $)$ & $2750 \pm 66$ & $1480 \pm 81$ & $4235 \pm 473$ \\
\hline 24) $\mathrm{N}\left(25 \mathrm{mM} \mathrm{NH}_{4} \mathrm{Cl}\right.$ solution $)$ & $2199 \pm 44$ & $2018 \pm 71$ & $4217 \pm 56$ \\
\hline 25) $\mathrm{P}+\mathrm{S}\left(20 \mathrm{mM} \mathrm{Na}_{2} \mathrm{HPO}_{4}\right.$ plus $50 \mathrm{mM} \mathrm{Na}_{2} \mathrm{SO}_{4}$ solution $)$ & $3274 \pm 79$ & $942 \pm 39$ & $4215 \pm 45$ \\
\hline 26) $\mathrm{K}+\mathrm{K}+\mathrm{K}+\mathrm{P}\left(12 \mathrm{mM} \mathrm{KCl}\right.$ plus $20 \mathrm{mM} \mathrm{Na}_{2} \mathrm{HPO}_{4}$ solution $)$ & $2984 \pm 28$ & $1211 \pm 95$ & $4195 \pm 58$ \\
\hline 27) $\mathrm{N}+\mathrm{S}\left(25 \mathrm{mM} \mathrm{NH}_{4} \mathrm{Cl}\right.$ plus $50 \mathrm{mM} \mathrm{Na}_{2} \mathrm{SO}_{4}$ solution $)$ & $2232 \pm 45$ & $1749 \pm 79$ & $3981 \pm 51$ \\
\hline 28) Control & $2433 \pm 60$ & $1211 \pm 79$ & $3644 \pm 64$ \\
\hline 29) USA Farmers' Yield & & & $1984[81]$ \\
\hline
\end{tabular}


(2 Units per $\mathrm{ml}$ of the extraction buffer solution) were added to the $0.1 \mathrm{M}$ Tris- $\mathrm{HCl} \mathrm{pH} 8$ extraction buffer [22] [23] [24]. After isoelectric focusing, the $\mathrm{pH}$ values of the Rotofor fractions were recorded before the fractions were dialyzed to remove the urea and ampholyte. Aliquots $(200 \mu \mathrm{L})$ of the dialyzed Rotofor fractions were subjected to native $7.5 \%$ polyacrylamide gel electrophoresis (Bio-Rad protean II xi cell) in duplicate. After the gel electrophoresis, one gel was stained with the phenazine methosulfate-glutamate-NAD ${ }^{+}$-tetrazolium bromide solution [22] in order to locate the positions of the GDH isoenzymes. GDH isoenzyme distribution pattern in the gel landscape was photo-documented. Using the stained gel as guide/template on a lightbox, the location of the GDH isoenzymes was excised from the duplicate electrophoresed gel [25]. The GDH isoenzymes were electro-eluted in $0.05 \mathrm{M}$ Tris- $\mathrm{HCl}$ solution from the excised piece of gel using Bio-Rad mini whole gel eluter at $-20^{\circ} \mathrm{C}[26]$. The fractions from the whole gel eluter were not combined.

\subsection{Synthesis of Cowpea Nongenetic Code-Based RNA Enzyme}

RNA synthetic activity of cowpea GDH hexameric isoenzymes was assayed in the amination substrate and deamination substrate solutions in separate tubes [12] [27]. The fractions from Bio-Rad whole gel eluter were combined as follows to make 6 groups:

Group 1: very acidic isoenzymes (pI 4.2) whole gel fractions 1 and 2.

Group 2: acidic isoenzymes (pI 5.1) whole gel fractions 3 and 4.

Group 3: mildly acidic isoenzymes (pI 6.3) whole gel fractions 5 and 6.

Group 4: neutral isoenzymes (pI 7.2) whole gel fractions 7 and 8.

Group 5: mildly alkaline isoenzymes (pI 8.0) whole gel fractions 9 and 10.

Group 6: alkaline isoenzymes (pI 8.5) whole gel fractions 11, 12, and 13.

For demonstrating the arrays of RNA synthesized in the amination direction, the substrate solutions were prepared in $0.1 \mathrm{M}$ Tris- $\mathrm{HCl}$ buffer $(\mathrm{pH} 8.0)$ containing the four ribo-NTPs (0.6 $\mathrm{mM}$ each), $\mathrm{CaCl}_{2}$ (3.5 mM), $\mathrm{NH}_{4} \mathrm{Cl}(0.875 \mathrm{mM})$, a-ketoglutarate $(10.0 \mathrm{mM}), \mathrm{NADH}(0.225 \mathrm{mM}), 5$ Units RNase inhibitor, 10 Units of DNase 1 , and $5 \mu \mathrm{g}$ of actinomycin D. The reaction cocktails were setup in six $15 \mathrm{~mL}$ centrifuge tubes on ice bath. The centrifuge tubes were numbered groups 1 to 6 for the GDH isoenzymes. Reaction was started by adding $0.4 \mathrm{~mL}$ of whole gel-eluted GDH isoenzymes containing $5-11 \mu \mathrm{g}$ protein per $\mathrm{mL}$ to the respective centrifuge tube. In order to capture the initial product RNA enzymes synthesized, reactions were incubated at $16^{\circ} \mathrm{C}$ for only $60 \mathrm{~min}$ and stopped by phenol-chloroform ( $\mathrm{pH}$ 5.5) removal of the proteins [28]. The RNA enzyme was precipitated with ethanol, the RNA was pelleted (6000 g, $15 \mathrm{~min}$ ), the pellet was air-dried to remove phenol and ethanol, then dissolved in minimum volume of molecular biology quality water; and stored at $-20^{\circ} \mathrm{C}$ before use. RNA enzyme yield and quality were verified by photometry and by agarose gel electrophoresis using RNA molecular weight markers as standards. The agarose gel was stained with ethidium bromide solution, and the RNA yield/distribution pattern was 
photo-documented.

In the deamination direction, the substrate solutions were prepared in $0.1 \mathrm{M}$ Tris- $\mathrm{HCl}$ buffer $\mathrm{pH} 8.6$ containing the four ribo-NTPs ( $0.6 \mathrm{mM}$ each), $\mathrm{CaCl}_{2}$ (3.5 $\mathrm{mM})$, L-glu $(3.23 \mu \mathrm{M}), \mathrm{NAD}^{+}(0.375 \mu \mathrm{M}), 5$ Units RNase inhibitor, 10 Units DNase 1 , and $5 \mu \mathrm{g}$ of actinomycin D [25]. The reaction cocktails were similarly setup in six $15 \mathrm{~mL}$ centrifuge tubes on ice bath. The centrifuge tubes were labeled groups 1 to 6 for the GDH isoenzymes. Reaction was started by adding 0.4 $\mathrm{mL}$ of whole gel-eluted GDH charge isomers containing 5 - $11 \mu \mathrm{g}$ protein per $\mathrm{mL}$ to the respective centrifuge tube. The purified GDH isoenzymes were same as those used for the amination reaction. In order to capture the initial product RNAs synthesized, reactions were incubated at $16^{\circ} \mathrm{C}$ for only $60 \mathrm{~min}$, and stopped by phenol-chloroform ( $\mathrm{pH}$ 5.5) removal of the proteins. The RNA enzyme was precipitated with ethanol, the RNA was pelleted (6000 g, $15 \mathrm{~min}$ ), the pellet was air-dried, and dissolved in minimum volume of molecular biology quality water; and stored at $-20^{\circ} \mathrm{C}$ before use. RNA enzyme yield and quality were verified by photometry and by agarose gel electrophoresis using RNA molecular weight markers as standards. The agarose gel was stained with ethidium bromide solution, and the RNA yield/distribution pattern was photo-documented.

Deamination and amination assays were carried out in duplicate (from the fast maturing seeds harvested) to verify the reproducibility of the growth of the crops and of the GDH assays. The GDH isoenzyme patterns for the duplicate seed harvest per experimental treatment of cowpea were similar. Duplicate seed yields that gave similar/identical GDH patterns per experimental treatment were then combined for other downstream analyses. GDH purification and GDH synthesis of RNA were completed within 3 weeks after cowpea seeds were harvested.

\subsection{Complementary DNA Synthesis and Sequencing}

cDNAs were synthesized with $2 \mu \mathrm{g}$ of each product RNA synthesized by the whole gel-eluted GDH isoenzymes in the deamination direction, and amination direction, using random hexamer primer. Digestion of the cDNA with taq 1 restriction enzyme; adapter and linker ligations to the restriction fragments; restriction fragment PCR amplification; sequencing gel fractionation; and purification of cDNA fragments [12] were conducted according to the methods of Display Systems Biotech, Vista, CA, USA. Selected cDNA fragments were subcloned into pCR4-TOPO vector and transformed into TOP10 One Shot Chemically Competent Escherichia coli (Invitrogen, Carlsbad, CA), followed by overnight growth on selective plates. Up to ten positive transformant colonies were picked per plate and cultured overnight in LB medium containing $50 \mu \mathrm{g} / \mathrm{mL}$ of kanamycin. Plasmid DNA was purified with a plasmid kit (Novagen, Madison, $\mathrm{WI}$ ). The insert cDNA was sequenced with $\mathrm{T} 3$ and $\mathrm{T} 7$ primers by Genemed Synthesis, Inc. (South San Francisco, CA, USA), and Functional Biosciences, Inc. (Madison, WI, USA). To identify the GDH-synthesized RNAs that were homologous to genetic code-based RNAs (mRNAs, tRNAs, and rRNAs) the cDNA 
sequences were used as queries to search the NCBI nucleotide-nucleotide (excluding ESTs) BLAST (blastn), and non-redundant protein translation (blastx) databases.

\section{Results and Discussion}

\subsection{GDH Hexameric Isoenzyme Population}

The two-dimensional electrophoretic purifications lined-up the cowpea GDH hexameric isoenzyme populations to a single horizontal row (Figure 1). But the intensities of individual hexamer bands were different from one stoichiometric mix of mineral nutrient treatment of the crop to the other. This is typical of GDH as it synthesizes RNAs and permutates the genetic, biochemical and physiological pathways in response to mineral nutrient composition and concentration [29].

\subsection{RNAs Synthesized by GDH}

They were low molecular weight RNAs, all of them being lower than 3 kilobases both in the deamination and amination directions (Figure 2) unlike in the peanut where the RNAs synthesized in the deamination direction were sharply different in molecular weight from those synthesized in the amination direction [27].

\section{Cowpea GDH Isoenzyme Populations}

Rotofor IEF Chambers

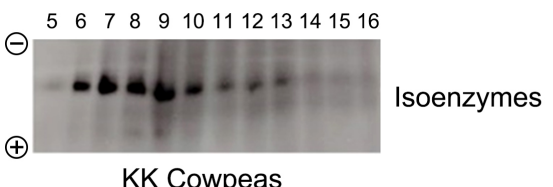

KK Cowpeas

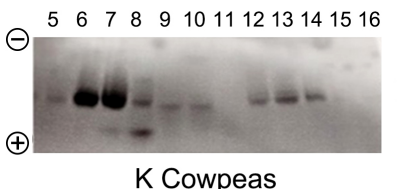

Isoenzymes

K Cowpeas

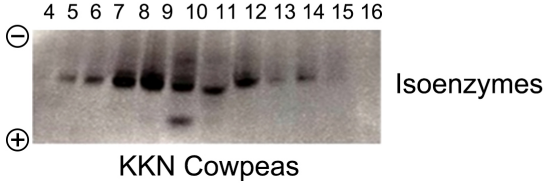

Rotofor IEF Chambers

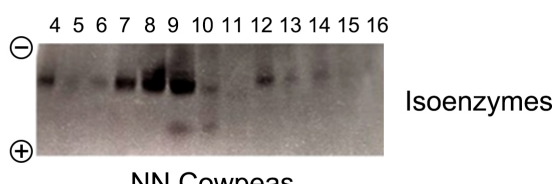

NN Cowpeas
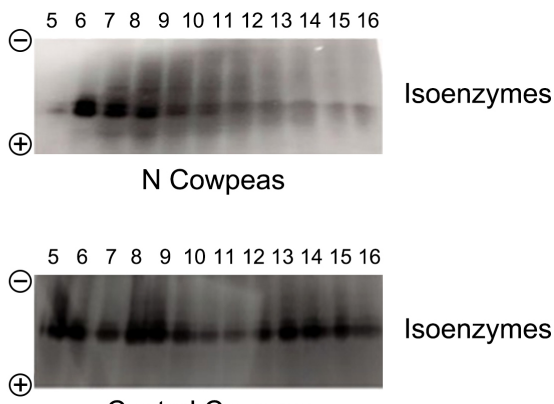

Control Cowpeas

Figure 1. Stoichiometric mineral nutrient-induced isomerization of cowpea GDH. GDH hexameric isoenzymes were isolated from equal weights of cowpea seeds harvested from control-untreated and from mineral nutrient-treated cowpeas; using Tris- $\mathrm{HCl}$ buffer cocktail containing RNase A, and DNase 1 . In each case, an equal volume of the GDH was subjected to Rotofor isoelectric focusing (IEF) to its vertical bands of hexameric isoenzymes. The pI values of the Rotofor fractions were recorded. After dialyzing the fractions, fraction numbers $5,6,7,8,9,10,11,12,13,14,15,16$ were fractionated by native polyacrylamide gel electrophoresis to the horizontal row of bands. The GDH hexameric isoenzyme profile was visualized by activity staining of the electrophoresed gel using tetrazolium bromide reagent. 

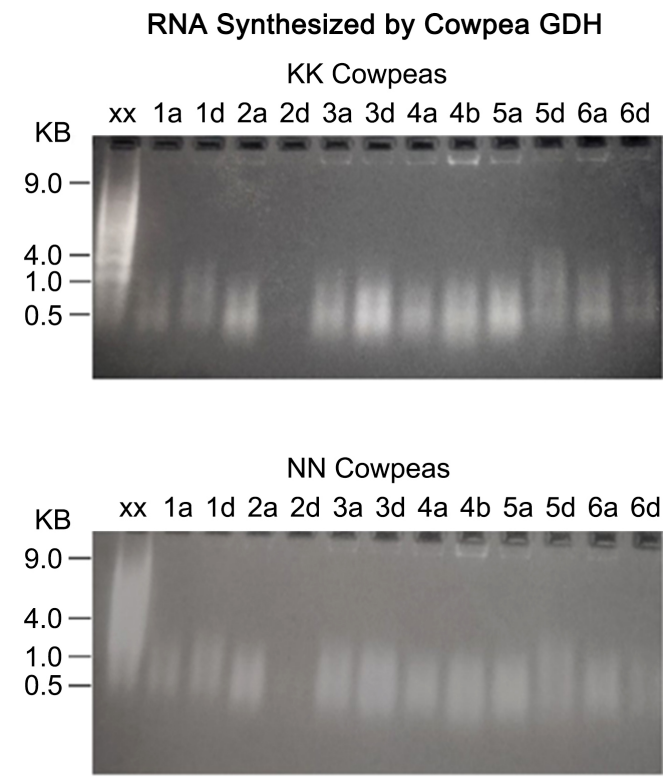

Control Cowpeas

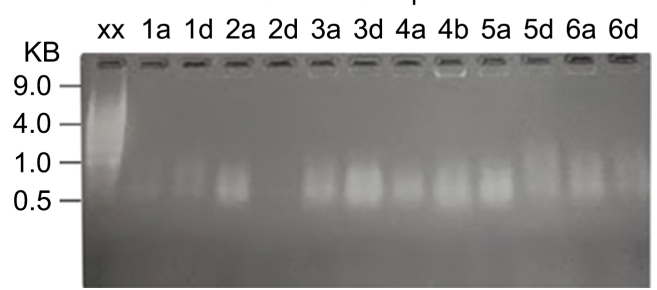

Figure 2. Nongenetic code-based RNAs synthesized by the GDH of control and stoichiometric mineral nutrient-treated cowpeas. The amination reaction cocktail contained $\mathrm{NADH}, \alpha-\mathrm{KG}$, the four ribo-NTPs, $\mathrm{CaCl}_{2}, 5$ Units of RNase inhibitor, 10 Units of DNase $1,5 \mu \mathrm{g}$ of actinomycin $\mathrm{D}$, and $\mathrm{NH}_{4} \mathrm{Cl}$ in $0.5 \mathrm{~mL}$ Tris- $\mathrm{HCl}$ buffer $\mathrm{pH}$ 8.0. Deamination reaction cocktail contained the four ribo-NTPs, $\mathrm{CaCl}_{2}, \mathrm{~L}$-glu, $\mathrm{NAD}^{+}, 5$ Units of RNase inhibitor, 10 Units of DNase 1, and $5 \mu \mathrm{g}$ of actinomycin D in $0.5 \mathrm{~mL}$ Tris- $\mathrm{HCl}$ buffer $\mathrm{pH}$ 8.6. GDH hexameric isoenzymes (about $5 \mu \mathrm{g}$ ) purified from the seeds of control and mineral nutrient-treated cowpea were added to each reaction. Reactions were incubated at $16^{\circ} \mathrm{C}$ for $1 \mathrm{~h}$. Product RNAs were electrophoresed through $2 \%$ agarose gel. XX is the RNA molecular weight marker. \#1 is the very acidic GDH isoenzymes (pI 4.2), \#2 is the acidic isoenzymes (pI 5.1), \#3 is the mildly acidic isoenzymes (pI 6.3), \#4 is the neutral isoenzymes (pI 7.2), \#5 is the mildly alkaline isoenzymes (pI 8.0), \#6 is the alkaline isoenzymes (pI 8.5). a is the RNA synthesized in the amination; $d$ is the RNA synthesized in the deamination cocktail.

The RNase and DNase that were added to the GDH extraction buffers hydrolyzed all the genetic code-based nucleic acids in the cowpea, and assured that the resulting oligonucleotide products were removed during the multi-dimensional electrophoretic purification of GDH hexamers.

\subsection{Sequencing Gel Fractionation and Sequences of the Restriction Fragments}

GDH amination reaction (left side) and deamination reaction (right side) were molecularly demonstrated in chemistry, visually real-time (Figure 3 ). The cDNA 
bands in Figure 3 lane A were reverse-transcribed from the RNAs synthesized in the aminating direction by the acidic GDH isoenzymes (pI 5.1); whilst the cDNA bands in Figure 3 lane E were reverse-transcribed from the RNAs synthesized in the deaminating direction by the same pI $5.1 \mathrm{GDH}$ isoenzymes. In this molecular chemistry approach, GDH amination was physically separated from the deamination reaction without introduction of any inhibitors into the reactions [9] [22].

The cDNA bands in Figure 3 lane B were reverse-transcribed from the RNAs synthesized by the mildly acidic GDH isoenzymes (pI 6.3) in the aminating direction; whilst the bands in Figure 3 lane $\mathrm{F}$ were reverse-transcribed from the RNAs synthesized by same mildly acidic GDH isoenzymes (pI 6.3) in the deaminating direction.

The cDNA bands in Figure 3 lane $\mathrm{C}$ were reverse-transcribed from the RNAs synthesized by the neutral GDH isoenzymes (pI 7.2) in the aminating direction; whilst the bands in Figure 3 lane $G$ were reverse-transcribed from the RNAs synthesized by same pI 7.2 neutral GDH isoenzymes in the deaminating direction.

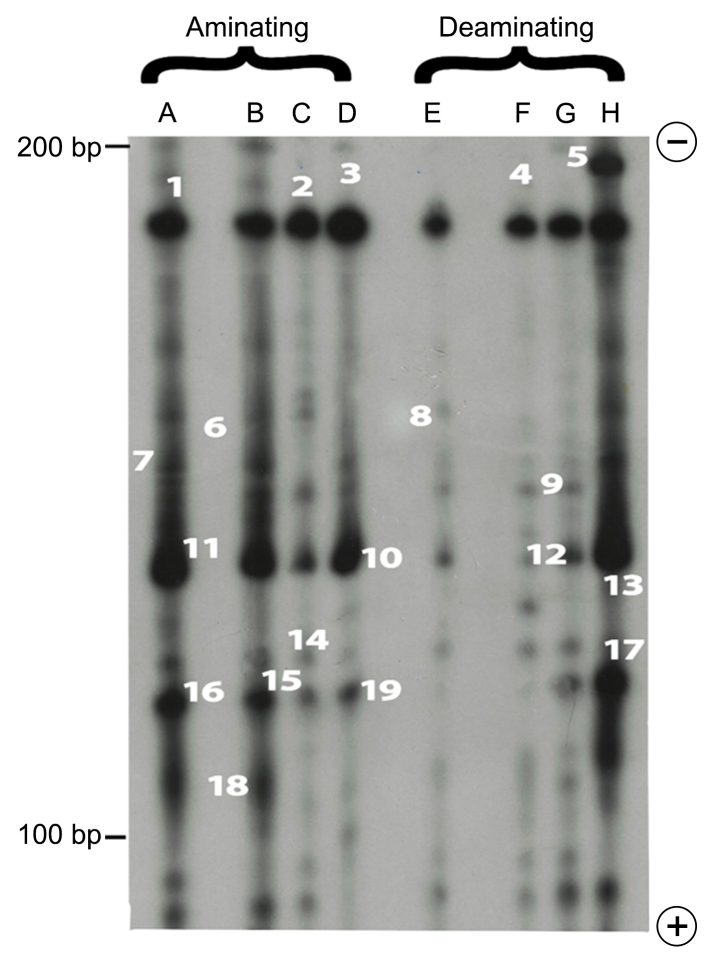

Figure 3. Differential display of the RNAs synthesized by cowpea GDH. The RNAs synthesized by the acidic isoenzymes (pI 5.1) in the amination direction (lane A), and deamination direction (lane $\mathrm{E}$ ); mildly acidic isoenzymes (pI 6.3) in the amination direction (lane B), and deamination direction (lane F); neutral isoenzymes (pI 7.2) in the amination direction (lane $\mathrm{C}$ ), and deamination direction (lane $\mathrm{G}$ ); mildly alkaline isoenzymes (pI 8.0) in the amination direction (lane $\mathrm{D}$ ), and deamination direction (lane $\mathrm{H}$ ) were used for cDNA synthesis using random hexamer primers. The cDNAs were digested with taq 1 restriction enzyme, the fragments were amplified by Double Differential PCR method, and the products were fractionated on sequencing polyacrylamide gel. The nucleotide sequences of the numbered bands are in Table 2. 
The cDNA bands in Figure 3 lane D were reverse-transcribed from the RNAs synthesized in the aminating direction by the mildly alkaline GDH isoenzymes (pI 8.0); whilst the bands in Figure 3 lane $\mathrm{H}$ were reverse-transcribed from the RNAs synthesized in the deaminating direction by same pI 8.0 mildly alkaline GDH isoenzymes.

The similarities in the GDH isoenzyme bands (Figure 1), and in the molecular weights of the nongenetic code-based oligonucleotide RNAs they synthesized (Figure 2) also characterized the cDNA band distribution patterns in the sequencing gel (Figure 3). But the apparently similar restriction fragment bands were made up of oligonucleotides of different nucleotide sequences (Table 2).

cDNA band \#3, reverse-transcribed from the RNA synthesized in the aminating conditions shared plus/minus sequence homology with cDNA band \#4 that was reverse-transcribed from the RNA synthesized in the deaminating conditions (Table 2, and Figure 3).

cDNA band \#3, reverse-transcribed from the RNA synthesized under aminating conditions shared plus/minus sequence homology with cDNA band \#5, reverse-transcribed from the RNA synthesized under deaminating conditions.

Table 2. mRNAs that are homologous to RNA enzymes synthesized by cowpea glutamate dehydrogenase isoenzymes.

Plasmid
$(\mathrm{S} / \mathrm{N})$$\quad$ RNA Enzyme Nucleotide Sequences $\quad$ mRNAs Homologous to the RNA Enzymes

\begin{tabular}{|c|c|c|}
\hline 1 & $\begin{array}{l}\text { ctggtctcgtagactgcgtacceggtcaggactcat } \\
\text { cgctactggtctcgtagactgcgtaatcggtcagga } \\
\text { ctcatcactactggtctcgtagactgcgtaccagcc } \\
\text { tggtaaggttcttcgcgttgattcggtcaggactcataa }\end{array}$ & $\begin{array}{l}\text { a) NADH-plastoquinone oxidoreductase: ref|YP_006460330.1|; } \\
\text { b) Phenylalanine ammonia-lyase gb|AAD45384.1|; } \\
\text { c) Phosphoribosylformylglycinamidine cyclo-ligase: } \\
\text { sp|P52424.1|PUR5_VIGUN; } \\
\text { d) Phosphoribosylpyrophosphate amidotransferase: gb|AAC24007.1| }\end{array}$ \\
\hline 2 & $\begin{array}{l}\text { actggtctcgtagactgcgtaccggcctggtaaggttcttcgcgttga } \\
\text { ttcggtcaggactcat }\end{array}$ & $\begin{array}{l}\text { a) Alternative oxidase gb|ABM66368.1|; } \\
\text { b) Dehydrin gb|AF159804.1|AF159804; } \\
\text { c) Formylglycinamide ribonucleotide amidotransferase gb|AAL55431.1|; } \\
\text { d) Phenylalanine ammonia-lyase gb|AAD45384.1|; } \\
\text { e) Phosphoribosylpyrophosphate amidotransferase gb|AAC24007.1|. }\end{array}$ \\
\hline 3 & $\begin{array}{l}\text { gggtcatagcggcgcgaaatcgcccttatgagtcctga } \\
\text { ccgaatcaacgcgaagaaccttaccaggccggtacgc } \\
\text { agtctacgagaccagtagtgatgagtcctgaccgatt } \\
\text { acgcagtctacgagaccagtagctatgagtcctgacc } \\
\text { gaatccgggtacgcagtctacgagaccagtaa }\end{array}$ & $\begin{array}{l}\text { a) Calcium exchanger protein gb|JQ731678.1|; } \\
\text { b) Digalactosyldiacylglycerol synthase: gb|ABA55727.1| } \\
\text { c) Glutathione reductase : gb|DQ267474.1| } \\
\text { d) NADH-plastoquinone oxidoreductase ref|YP_006460330.1|; } \\
\text { e) Sulfoquinovosyldiacylglycerol synthase: gb|DQ205522.1| }\end{array}$ \\
\hline 4 & $\begin{array}{l}\text { ggtaattgcgggegcgaattcgcccttactggtctcgtaga } \\
\text { ctgcgtaccggcctggtaaggttcttcgcgttgattcggtca } \\
\text { ggactcata }\end{array}$ & $\begin{array}{l}\text { a) Alternative oxidase gb|ABM66368.1|; } \\
\text { b) Ascorbate peroxidase (chloroplast stroma) gb|AAS55853.1|; } \\
\text { c) Ascorbate peroxidase (chloroplast thylakoid): gb|AAS55852.1|; } \\
\text { d) Cytochrome b6: ref|YP_006460372.1|; } \\
\text { e) Formylglycinamide ribonucleotide amidotransferase (pur4) } \\
\text { gb|AAL55431.1|; } \\
\text { f) NADH-plastoquinone oxidoreductase ref|YP_006460330.1|; } \\
\text { g) Phenylalanine ammonia-lyase gb|AAD45384.1|; } \\
\text { h) Phosphoribosylpyrophosphate amidotransferase gb|AAC24007.1|; } \\
\text { i) Starch synthase emb|CAB40374.1| }\end{array}$ \\
\hline
\end{tabular}


actggtctcgtagactgcgtacccgaatggattggaaagga

5 atagaatggaatggaatggaatcgactcaaatggaatggac tagaatggaatggattcggtcaggactcata a) Aminoimidazole ribonucleotide synthase (pur5)

gb|U30895.1|VUU30895;

b) Ascorbate peroxidase gb|AAS46016.1|;

c) Ascorbate peroxidase (chloroplast stroma) gb|AY484493.1|;

d) Asparagine synthase dbj|BAM93579.1|;

e) Glycin-rich protein emb|X87948.1|;

f) Phenylalanine ammonia-lyase gb|AAD45384.1|;

g) Glycinamide ribonucleotide synthase (pur2)

gb|U30896.1|VUU30896;

h) Phenylalanine ammonia-lyase: gb|AF165998.1|AF165998;

i) Phosphoribosylpyrophosphate amidotransferase (pur1)

gb|AF071862.2|;

j) Ribulose-bisphosphate carboxylase/oxygenase gb|AER24546.1|;

k) Starch synthase emb|AJ225088.1|;

1) Vicilin : emb|AM905848.1|;

m) Asparagine synthase dbj|AB779664.1|

n) Isoflavone synthase 2: gb|EU737111.1| ataaggggtctttgcgggcgcgtatcgccgtattgagtcctgaccgaat

caacgcgaagaaccttaccaggccggtacgcagtctacgagacc

agtagtatgagtcctgaccgattacgcagtctacgagaccagtagct

atgagtcctgaccgaatccgggtacgcaatc aacgagaccag a) Apoprotein A2 P700 photosystem 1 ref|YP_006460336.1|;

b) Aspartic proteinase gb|AF287258.1|;

c) Cytochrome b6 ref|YP_006460372.1|;

d) Glutathione reductase gb|DQ267474.1|. ataaggggtctttgcgggcgcgtatcgccgtattgagtcctgaccgaatcaacgcg

7 aagaaccttaccaggccggtacgcagtctacgagaccagtagtgatgagtcctgacc gattacgcagtctacgagaccagtagctatgagtcctgaccgaatccgggtacgcaat caacgagaccagtaag a) Calcium exchanger protein $\mathrm{gb}|\mathrm{KC} 404642.1|$;

b) Glutathione reductase gb|DQ267474.1|;

c) Starch synthase: gb|ABP35818.1| gggtatagcggncgcgnattcgcccttactggtctcgtagactgcg tacccgatgcagaaggcgggaaaacatgaaatgagcgtcaagca ggccgtgaaggttgccgagcttttgaagtgcaacccgatggagg tatctgcggggtgatgtttcaccaggacgtaatggagcgggattt ctggacggacattttccagcagacagtcaccgaaaacgaccgcc gccactacttcaagaaggtttaggcaggctttcggtcaggactcataa a) Aminoimidazolecarboximide ribonucleotide-transformylase/ inosine monophosphate cyclohydrolase gb|AY193836.1|;

b) Glycinamide ribonucleotide synthetase (pur2) gb|U30896.1|VUU30896;

c) Isoflavone synthase gb|EU616499.1|;

d) Shatterproof-like protein gb|AEO89558.1| gcgtaataggcggcgcgaattcgccettactggtctcgtagactgcgta cccgatgcagaaggcgggaaaacatgaaatgagcgtcaagcaggccg tgaaggttgccgagcttttgaagtgcaacccgatggaggttatctgcgg ggtgatgtttcaccaggacgtaatggagcgggatttctggacggacatt ttccagcagacagtcaccgaaaacgaccgccgccactacttcaagaag gtttaggcaggctttcggtcaggactcata a) Aminoimidazolecarboximide ribonucleotide-transformylase/ inosine monophosphate cyclohydrolase gb|AY193836.1|;

b) Apyrase dbj|AB196770.1|;

c) Glycinamide ribonucleotide synthetase (pur2) gb|U30896.1|VUU30896;

d) Glycinamide ribonucleotide tranformylase (pur3) gb|AY189138.1|;

e) Shatterproof-like protein gb|AEO89558.1|;

f) Starch synthase gb|ABP35818.1|. ggctaatagcggcgcgaattcgccettatgagtcctgaccgaatcaacg cgaagaaccttaccaggccggtacgcagtctacgagaccagt a) Drought inducible protein $\mathrm{dbj}|\mathrm{D} 83972.1|$;

b) Formylglycinamide ribonucleotide amidotransferase gb|AAL55431.1|;

c) Fructokinase: gb|HM211406.1|;

d) Phenylalanine ammonia-lyase gb|AAD45384.1|;

e) Phosphoribosylpyrophosphate amidotransferase gb|AAD45384.1|

f) Apyrase dbj|BAD80836.1|

g) $\gamma$-ATP synthase sp|Q2LGZ2.1|ATPG_VIGUN

h) Ferric leghemoglobin reductase gb|AF181096.1|AF181096 


\section{Continued}

ggggaatagcgggcgcgtattcgcccttactggtctcgtagactgcgtacccgatg cagaaggcgggaaaacatgaaatgagcgtcaagcaggccgtgaaggttgccgag

11 cttttgaagtgcaacccgatggaggttatctgcggggtgatgtttcaccaggacgtaa tggagcgggatttctggacggacattttccagcagacagtcaccgaaaacgaccgc cgccactacttcaagaaggtttaggcaggctttcggtcaggactcataa a) Isoflavone synthase $1 \mathrm{gb} \mid \mathrm{EU} 737110.2$ a) Apyrase: gb|AF156781.1|AF156781;

b) Carbonic anhydrase: gb|JQ429799.2|;

c) 4-Coumarate:coenzyme A ligase 7: gb|KF303292.1|;

d) Glycine-rich cell wall protein $1.8 \mathrm{emb}|\mathrm{X} 13596.1|$;

e) Glycinamide ribonucleotide synthase (pur3) gb|AF160196.2|;

f) Isoflavone synthase 1: gb|EU737110.2 | ggatatagcggncgcgnattcgccettactggtctcgtagactgcgtacccggtcag gactcatcgcttctggtctcgtagactgcgtaatcggtcaggactcatcactactggtc tcgtagactgcgtaccggcctggtaaggttcttcgcgttgattcggtcaggactcataag
Glutathione reductase gb|DQ267474.1|

a) Calcium exchanger protein gb|JQ731678.1|;

b) Delta 1-pyrroline-5-carboxylate synthase dbj|AB518058.1|;

c) Glutathione reductase gb|DQ267474.1|.
14 tgaccgagtacgcagtctacgagaccagtagcgatgagtcctgaccgggtacgca gtctacgagaccagta
a) Apyrase gb|AF156781.1|AF156781
b) Extensin emb|X91836.1|
c) Lectin precursor emb|AJ621421.1| actacttcaagaaggtttaggcaggctttcggtcaggactcataa

gggtaatagcggcgcgaattcgcccttactggtctcgtagactgcgtact cggtcaggactcatcgctactggtctcgtagactgcgtacccggtcagga ctcgtcactactggtctcgtagactgcgtaccggcctggtaaggttcttc gcgttgattcggtcaggactc
a) Phosphoenolpyruvate carboxylase gb|ACO48250.1|;
b) Triacylglycerol lipase $1 \mathrm{gb}|\mathrm{ADY} 38373.1|$

gcgtgatagcggcgcgaaatcgccettactggtctcgtagactgcgtacccgatg cagaaggcgggaaaacatgaaatgagcgtcaagcaggccgtgaaggttgccga

17 gctttgaagtgcaacccgatggaggttatctgcggggtgatgtttcaccaggacg taatggagcgggatttctggacggacattttccagcagacagtcaccgataacga ccgccgccactacttcaagaaggtttaggcaggctttcggtcaggactcataa
a) Apyrase gb|AF156781.1|AF156781;
b) Drought inducible protein: $\mathrm{dbj} \mid \mathrm{D} 83970.1$;
c) Isoflavone synthase $1 \mathrm{gb} \mid \mathrm{EU} 737110.2$;
d) Lectin precursor emb|AJ621421.1|

gggtatagcggncgcgcattcgeccttatgagtcctgaccgaatcaacgcgaagaa ccttaccaggccggtacgcagtctacgagaccagta a) Cytochrome b6 gb|AEP94890.1|;

b) Formylglycinamide ribonucleotide amidotransferase

gb|AAL55431.1|;

c) NADH-plastoquinone oxidoreductase ref|YP_006460330.1|;

d) Phenylalanine ammonia-lyase gb|AAD45384.1|;

e) Phosphoribosylpyrophosphate amidotransferase gb|AAC24007.1|

f) Xeaxanthin epoxidase (CpABA1): dbj|AB030295.1|; dbj|BAB11934.1| actggtctcgtagactgcgtacccgaatgggttggaaaggaatagaatggaatggaa tggaatcgactcaaatggaatggactagaatggaatggattcggtcaggactcataa a) Aminoimidazole ribonucleotide carboxylase gb|AAL48287.1|AF4524951;

b) Ascorbate peroxidase: gb|AAS46016.1|;

c) Asparagine synthase: dbj|BAM93579.1|;

d) Carbonic anhydrase gb|AFX73760.1|;

e) Phenylalanine ammonia-lyase gb|AAD45384.1|;

f) Ribulose-bisphosphate carboxylase/oxygenase gb|AER24546.1|;

g) Starch synthase : emb|CAB40374.1|

h) Xeaxanthin epoxidase (CpABA1) dbj|BAB11934.1| 
cDNA band \#10, reverse-transcribed from the RNA synthesized under aminating conditions shared plus/minus sequence homology with cDNA band \#5 reverse-transcribed from the RNA synthesized under deaminating conditions.

cDNA band \#3, reverse-transcribed from the RNA synthesized under aminating conditions shared plus/minus sequence homology with cDNA band \#13, reverse-transcribed from the RNA synthesized under deaminating conditions.

cDNA band \#10, reverse-transcribed from the RNA synthesized under aminating conditions shared plus/minus sequence homology with cDNA band \#4, reverse-transcribed from the RNA synthesized under deaminating conditions.

cDNA band \#10, reverse-transcribed from the RNA synthesized under aminating conditions shared plus/minus sequence homology with cDNA band \#17, reverse-transcribed from the RNA synthesized under deaminating conditions.

cDNA band \#10, reverse-transcribed from the RNA synthesized under aminating conditions shared plus/minus sequence homology with cDNA band \#9, reverse-transcribed from the RNA synthesized under deaminating conditions.

Therefore, the RNAs synthesized by GDH under amination conditions were plus-RNA, those synthesized under deamination conditions were minus-RNAs. These molecular biology models (Figure 3 ) of the opposite chemical differences in RNA primary structure illuminate the hitherto inexplicable phenomena shrouding the reductive amination and the oxidative deamination activities of $\mathrm{GDH}$, and are crucially important for understanding the molecular basis of the low grain yields of cowpea. They confirm that the synthesis of RNAs is a cycle (Figure 4) of different irreversible chemical reactions driven by $\mathrm{NADH} / \mathrm{NAD}^{+}$, and $\alpha-\mathrm{KG} / \mathrm{L}-\mathrm{Glu} / \mathrm{NH}_{4}^{+}$(Figure 3 ) couples rather than a classical reversible oxidation-reduction reaction. The plus/minus RNA synthesis by GDH isoenzymes further confirms the existence of orientation and positionality of the subunit polypeptides in the active hexameric isoenzymes [20], a structure that only the electrophoretic purification steps preserved (Figure 1, and Figure 2). In the GDH cycle model (Figure 3, Figure 4), the plus-RNA is not reversibly oxidized to minus-RNA. Conversely, the minus-RNA is not reduced to plus-RNA. The GDH cycle (Figure 4) for the synthesis of minus-RNA and plus-RNA is non-reversible. Therefore, the function of NADH/NAD ${ }^{+}$, and $\alpha-K G / L-G l u / N_{4}^{+}$ in biology is to establish the redox homoeostasis so that GDH can synthesize plus-RNA and minus-RNA. In a single sweep of the cycle, GDH isoenzymes synthesized double the quantity of RNA products of opposite primary structures (Figure 4). This made for economy in the utilization of $\mathrm{NADH} / \mathrm{NAD}^{+}$, and of $\alpha-\mathrm{KG} / \mathrm{L}-\mathrm{Glu} / \mathrm{NH}_{4}^{+}$. The plus-RNA, and minus-RNA synthesis is the core of the molecular chemistry of GDH; ensuring that the nongenetic code-based RNA enzymes are very complicated in primary and secondary structures to match the equally complex structures of the mRNA they degrade [10] [21]. No other template-independent RNA polymerization apparatus is able to synthesize two types of opposite polarity complicated RNAs simultaneously with such astonishing chemical repeatability and fidelity. The synthesis of complicated plus-RNA and 


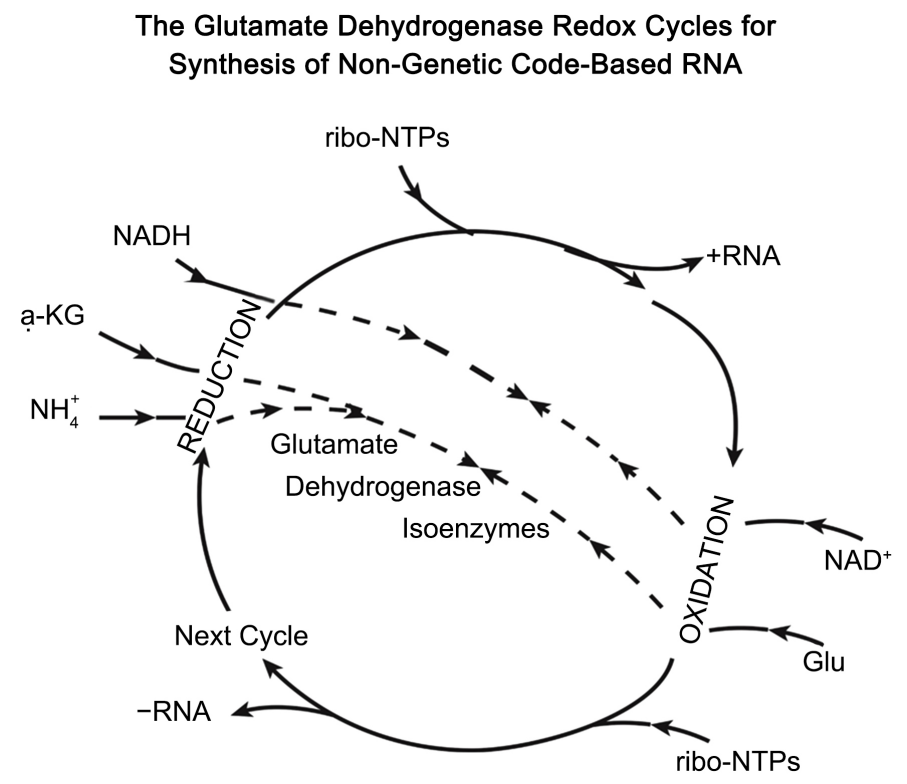

Figure 4. Discovery of glutamate dehydrogenase redox cycles that synthesize nongenetic code-based plus-RNA in the amination direction, and minus-RNA in the deamination direction.

minus-RNA by GDH is crucial for understanding the dry grain yield molecular biology of the cowpeas. Hexameric isoenzymes of GDH may henceforth be assayed comprehensively by monitoring the kinetic and thermodynamic transformations of the $\mathrm{NADH} / \mathrm{NAD}^{+}$, and $\alpha-\mathrm{KG} / \mathrm{L}-\mathrm{Glu} / \mathrm{NH}_{4}^{+}$homeostasis at the protein level [17] [18] [19] [30] [31] [32] [33] [34], and by sequencing the plus-RNA and minus-RNA at the molecular chemistry level (Table 2). Measurement of the transactions of the redox homoeostasis without sequencing the product nongenetic code-based RNAs, does not unfold the molecular chemistry and functions of the enzyme.

The yields of the RNA fragments synthesized in the amination direction by the acidic, and mildly acidic GDH isoenzymes (Figure 3 lanes A, and B), were visibly higher than those synthesized by the same GDH hexameric isoenzymes in the deamination direction. Also, the yields of RNA fragments synthesized by the mildly alkaline GDH isoenzymes (Figure 3 lane $\mathrm{H}$ ) in the deamination direction were higher than those they synthesized in the amination direction (Figure 3 lane D). These observations suggest that the GDH cycle (Figure 4) consists of two sub-cycles of unequal activities in the synthesis of RNA; the acidic, mildly acidic, and neutral GDH isoenzymes being very active in the amination direction, whereas the mildly alkaline isoenzymes were more active in the deamination direction in purple hull cowpea.

\subsection{Functions of GDH-Synthesized RNA of Cowpea}

Nongenetic code-based RNA synthesized by GDH aligns with its homologous genetic code-based RNA to degrade it because nongenetic code-based RNA is more thermostable than genetic code-based RNA [10]. Homologous RNA 
strands are held together by hydrophobic forces including van der Waal's forces, non-Watson Crick bonds etc. [35]. Removal of the structural constraints imposed by genetic code transforms RNA to a fully-fledged RNA enzyme that is independent of genetic code for its biochemical function [21]. Nongenetic code-based RNA synthesized by hexameric GDH is RNA enzyme [10] [21].

cDNA fragment \#1 (that is, RNA fragment \#1, Table 2) shared sequence homologies with the mRNAs encoding NADH plastoquinone oxidoreductase that catalyzes the Photosystem II light harvesting reaction in oxygenic photosynthesis [36]; phophoribosylformylglycinamidine cyclo-ligase that transports single-carbon groups in folate, methionine, and cysteine biosynthesis [37]; phenylalanine ammonia-lyase; and phosphoribosyl pyrophosphate amidotransferase. Phospho ribosyl pyrophosphate is utilized in the biosynthesis of purine and pyrimidine nucleotides, histidine and tryptophan, and nicotinamide adenine dinucleotide [38]. Phenylalanine ammonia-lyase (PAL) catalyzes the nonoxidative deamination of phenylalanine to form ammonium ion and trans-cinnamic acid, the entry step for the channeling of carbon from primary metabolism into phenylpropanoid secondary metabolism in plants. PAL enables cowpeas to respond to environmental stimuli [39]. Therefore, RNA fragment \#1 regulates the growth and yield of cowpea by regulating the abundance of the mRNAs that are homologous to it. Regulation of the abundance of genetic code-based RNAs by nongenetic code-based RNAs has been demonstrated repeatedly in peanut growth and yield [9] [10] [12] [17] [18] [21] [25] [29].

RNA fragment \#2 (Table 2) shared sequence homologies with the mRNAs encoding alternative oxidase, dehydrin, formylglycinamide ribonucleotide amidotransferase of the purine biosynthetic pathway [40], phenylalanine ammonia-lyase, and phosphoribosylpyrophosphate amidotransferase. Alternative oxidase catalyzes cyanide-resistant reduction of oxygen to water without translocation of protons across the inner mitochondrial membrane, and thus functions as a non-energy-conserving component of the respiratory electron transfer chain [41]. Dehydrins are membrane proteins that reduce electrolyte leakage from cowpea seedlings thereby conferring low temperature tolerance [42]. Therefore, RNA fragment \#2 controlled the growth and yield in cowpea by regulating the abundance of the mRNAs that are homologous to it.

RNA fragment \#3 (Table 2) shared sequence homologies with the mRNAs encoding calcium exchanger protein, NADH plastoquinone oxidoreductase, digalactosyldiacylglycerol synthase, sulfoquinovosyldiacylglycerol synthase, and glutathione reductase. Calcium exchanger protein regulates the concentration of calcium ions in cowpea roots in relation to soil calcium ion concentrations [54]. Digalactosyldiacylglycerol is a chloroplast precursor in the middle lamellar prothylakoids membrane systems complexed with NADPH light-dependent oxidoreductase [43]. Sulfoquinovosyldiacylglycerol and phosphatidylglycerol are major classes of the thylakoid membrane lipids in higher plant chloroplasts where they are essential for photosynthesis and growth [44]. Glutathione/glutathione 
disulfide (GSH/GSSG) redox buffer provides homeostasis by maintaining the redox state of other thiol compounds, avoiding their unnecessary oxidation and thus keeping them in the reduced state. GSH also detoxifies xenobiotics, sequesters heavy metals involved in environmental stress tolerance in cowpeas [45]. Therefore, RNA fragment \#3 controlled the growth and yield of cowpea by regulating the abundance of the mRNAs that are homologous to it.

RNA fragment \#4 (Table 2) shared homologous sequences with the mRNAs encoding alternative oxidase, ascorbate peroxidases, formylglycinamide ribonucleotide amidotransferase, NADH plastoquinone oxidoreductase, phenylalanine ammonia-lyase, cytochrome b6, starch synthase, and phosphoribosylpyro-phosphate amidotransferase. Starch is an insoluble polymer of glucose residues, and is a major storage product of seeds and storage organs produced agriculturally and used for human food. Transient starches synthesized in leaves in the day are hydrolyzed at night to provide carbon for non-photosynthetic metabolism [20] [46]. Cytochrome b6 complex balances the photosynthetic production of ATP and $\mathrm{NADPH}$ with their metabolic consumption in the Calvin-Benson cycle and the subsequent reactions of primary metabolism [47]. Ascorbate and glutathione, non-enzymatic antioxidants are important for cowpea defense against oxidative stress, playing a key role as antioxidant buffers [48]. RNA fragment \#4 controlled the abundance of the mRNAs that share sequence homology with it, and therefore cowpea growth and yield.

RNA fragment \#5 (Table 2) was homologous to the mRNAs encoding peroxidases, aminoimidazole ribonucleotide synthase, asparagine synthase, glycine-rich protein, phenylalanine ammonia-lyase, glycinamide ribonucleotide synthase, starch synthase, phosphoribosyl pyrophosphateamido transferase, ribulose-bisphosphate carboxylase/oxygenase, vicilin, and isoflavone synthase. Fragment \#5 was repeated five times in the mRNA encoding glycine-rich protein; two times with the mRNA encoding starch synthase; and two times with the mRNA encoding aminoimidazole ribonucleotide synthase. These repeat matches within the length of an mRNA make for fail-proof alignment in the intermediate [GDH synthesized RNA: mRNA] enzyme: substrate complex [10]. Aminoimidazole ribonucleotide synthase is one of the ten enzymes involved in purine biosynthesis [40]. Asparagine plays a central role in nitrogen storage and transport in higher plants due to its high ratio of nitrogen to carbon and its unreactive nature. It accumulates to high concentrations during seed germination and in response to abiotic and biotic stresses [49]. Glycine-rich proteins are accumulated in the vascular tissues and their synthesis is part of cowpea's defense mechanism against stress [50]. Glycinamide ribonucleotide synthase is involved in purine and pyrimidine nucleotide biosynthesis [51]. Ribulose-bisphosphate carboxylation is the major rate determining reaction in photosynthetic $\mathrm{CO}_{2}$ assimilation. All factors that influence the photosynthetic rate do so by influencing the activity of ribulose-bisphosphate carboxylase/oxygenase and the concentration of its substrates, $\mathrm{CO}_{2}$ and ribulose-bisphosphate [52]. Vicilins, also called 7S 
globulins are storage proteins and constitute as much as $70 \%$ to $80 \%$ of total seed protein. They are cleaved into smaller fragments before and during the germination process, and may play defensive roles in germinating seeds [53]. Isoflavones in the rhizosphere soil induce the expression of rhizobial Nod genes, which initiate the formation of the nodules that fix nitrogen. In addition, isoflavones act as antimicrobial phytoalexins and modulate rhizosphere microbial communities, which have been suggested to play important roles in cowpea growth and yield [54]. Therefore, RNA fragment \#5 regulated the growth and yield of cowpea by controlling the abundance of the mRNAs that are homologous to it.

RNA fragment \#6 (Table 2) was homologous to the mRNAs encoding apoprotein A2 P700 photosystem 1, aspartic proteinase, cytochrome b6, and glutathione reductase. Photosystem I mediates light-driven electron transfer from plastocyanin to ferredoxin and is involved in light energy conversion by balancing linear and cyclic electron transport in photosynthesis [55]. Aspartate proteinase is involvement in protein processing and degradation under different conditions and in different stages of cowpea development suggests some stress-related functional specialization [56]. Therefore, RNA fragment \#6 controlled the growth and yield of cowpea by regulating the abundance of the mRNAs that are homologous to it.

RNA fragment \#7 (Table 2) shared sequence homology with the mRNAs encoding calcium exchanger protein, glutathione reductase, and starch synthase. The RNA fragment controlled the abundance of the mRNAs that share sequence homology with it, and therefore cowpea development and yield.

RNA fragment \#8 (Table 2) shared sequence homology with the mRNAs encoding isoflavone synthase, aminoimidazolecarboximide rionucleotide transformylase or inosine monophosphate cyclohydrolase, glycinamide ribonucleoside synthetase, and shatterproof-like protein. Control of pod shattering trait was an important trait and step that led to the domestication of cowpea, a protein-rich staple crop of the world [57]. RNA fragment \#8 controlled the abundance of the mRNAs that shared sequence homology with it, and therefore cowpea growth and yield.

RNA fragment \#9 (Table 2) shared sequence homology with the mRNAs encoding, shatter-proof-like protein, granule-bound starch synthase, apyrase, glycinamide ribonucleotide transformylase, and aminoimidazolecarboximide rionucleotide transformylase/inosine monophosphate cyclohydrolase. RNA fragment \#9 was repeated two times in the mRNA encoding apyrase. Apyrase is localized in the plasma membrane. Its nucleoside triphosphate diphosphohydrolase activity stimulates nodulation in legumes by regulating nucleotide concentration in the extracellular matrix [58]. Aminoimidazolecarboximide ribonucleotide is used in the synthesis of the purine ring in plant cells because the products, AMP and GMP, provide purine bases for DNA and RNA, as well as for a number of coenzymes (NAD, NADP, FAD, and coenzyme A) and signaling molecules. ATP serves as the energy source for many chemical reactions. Also, nucleotides are the precursors for purine alkaloids, and for the adenine moiety of cytokinin, the 
plant growth regulator [59]. Therefore, RNA fragment \#9 controlled the growth and yield of cowpea by regulating the abundance of the mRNAs that were homologous to it.

RNA fragment \#10 (Table 2) shared sequence homology with the mRNAs encoding drought inducible protein, apyrase, formylglycinamide ribonucleotide amidotransferase, fructokinase, phenylalanine ammonia-lyase, phosphoribosylpyrophosphate amidotransferase, gamma-ATP synthase, and ferric leghemoglobin reductase. Drought inducible protein protects cowpea cell wall during dehydration, and high-salinity stresses. Abscisic acid levels rose 160 times in the drought-stressed cowpeas [60]. Leghemoglobin is the heme-containing protein that reversibly binds and transports $\mathrm{O}_{2}$ into the $\mathrm{N}_{2}$-fixing nodules of leguminous plants. In order to function as an $\mathrm{O}_{2}$-carrier, leghemoglobin is in the ferrous oxidation state. Oxygenated leghemoglobin readily autoxidizes to ferric leghemoglobin releasing the reactive $\mathrm{O}_{2}^{-}$species for the symbiotic metabolism [61].

RNA fragment \#11 (Table 2) shared sequence homology with the mRNA encoding isoflavone synthase.

RNA fragment \#12 (Table 2) shared sequence homology with mRNAs encoding apyrase, carbonic anhydrase, coumarate coenzyme A ligase, glycine-rich cell wall protein, isoflavone synthase, and glycinamide ribonucleotide synthase. Carbonic anhydrase catalyzes the reversible hydration of $\mathrm{CO}_{2}$ in photosynthesis. It establishes the required inorganic carbon species equilibration so that the slow, uncatalyzed rate of $\mathrm{CO}_{2} / \mathrm{HCO}_{3}^{-}$interconversion does not limit the rate of photosynthesis [62].

RNA fragment \#13 (Table 2) shared sequence homology with the mRNA encoding glutathione reductase.

RNA fragment \# 14 (Table 2) shared sequence homology with the mRNAs encoding calcium exchanger protein, delta 1-pyrroline-5-carboxylase synthase, and glutathione reductase. A bifunctional enzyme, delta-1-pyrroline-5-carboxylase synthase catalyzes the first two steps in proline biosynthesis in plants. Drought is among the most important environmental factor that causes osmotic stress and impacts negatively on plant growth and crop productivity. To counter this stress, many plants increase the osmotic potential of their cells by synthesizing and accumulating compatible osmolytes such as proline and glycine betaine [63].

RNA fragment \#15 (Table 2) shared sequence homology with the mRNAs encoding apyrase, extensin, and lectins. Extensins are the self-assembling amphiphiles that generate scaffolding networks and pectic matrix for the physiological formation of cell wall [64]; and observed in rhizobium-cowpea interaction [65]. Lectins are carbohydrate-specific proteins for signal recognition and communication across the cell wall [66].

RNA fragment \#16 (Table 2) shared sequence homology with the mRNAs encoding phosphoenolpyruvate carboxylate, and triacylglycerol lipase. Phosphoenolpyruvate is the starting intermediate for the biosynthesis of tryptophane, phenylalanine, and tyrosine in peanut [67]. Triacylglycerol protects plants from 
fungi, and insect pests.

RNA fragment \#17 (Table 2) was homologous to the mRNAs encoding apyrase, drought inducible protein, isoflavone synthase, and the enzyme for lectin biosynthesis.

RNA fragment \#18 (Table 2) shared sequence homology with the mRNAs encoding cytochrome b6, formylglycinamide ribonucleotide amidotransferase, NADH-plastoquinone oxidoreductase, phenylalanine ammonia lyase, phosphoribosylpyrophosphate amidotransferase, and xeaxanthin epoxidase.

RNA fragment \#19 (Table 2) shared sequence homology with the mRNAs encoding aminoimidazole ribonucleotide carboxylase, ascorbate synthase, asparagine synthase, carbonic anhydrase, starch synthase, phenylalanine ammonia-lyase, ribulose-bisphosphate carboxylase/oxygenase, and xeaxanthin epoxidase. Zeaxanthin epoxidase plays an important role in the xanthophyll cycle and abscisic acid biosynthesis. It converts zeaxanthin into antheraxanthin and subsequently violaxanthin. It is required for resistance to osmotic and drought stresses, regulation of seed development and dormancy, modulation of defense gene expression and disease resistance, and non-photochemical quenching in cowpea [68].

The nongenetic code-based RNA enzymes (Table 2) are oligonucleotides that shared sequence homologies with an average of six different mRNAs of cowpea. When environmental conditions are inadequate (commercial fertilizer composition and concentration, extreme temperature, drought, low organic carbon contents of soil, biotic factors etc), the GDH hexamers synthesize a lot of RNA fragments that degrade the homologous mRNAs encoding most of the regulatory enzymes, thereby discriminating/permuting the biochemical pathways; and the crop yield is low (Table 1). Conversely, when the environmental conditions are excellent (stoichiometric mineral salts, healthy soil, normal temperatures, rain fall etc), the GDH hexamers synthesize only some RNA so that most of the cowpea biochemical pathways remain functional and integrated to optimize and maximize the grain yield [11].

\subsection{Biochemical Pathways of GDH-Synthesized RNA Enzymes in Cowpeas}

The RNA synthesized by GDH, being nongenetic code-based, is not subject to the biological and physical constraints imposed by genetic code [21]. Complete freedom from the molecular restrictions of the genetic code empowers the GDH-synthesized RNA to be thermally stable, and to exercise chemical functions of RNA enzyme [10] to degrade homologous genetic code-based RNA (total RNA). Other known RNA enzymes are different, being genetic code-based RNA hydrolyzing genetic code-based RNA through Watson-Crick base pairing mechanism; therefore, their scopes are limited [10]. The enzymatic activities of GDH-synthesized RNAs in peanut have been demonstrated in vivo, and in vitro, deduced from the modeling of the coordinated complex networks of GDH bio- 
chemical pathways [11] [29]. The RNAs synthesized by any group of peanut GDH isoenzymes completely degraded all the total RNA substrate under in vitro chemical reaction condition. Total RNA is a complex mixture of the transcriptome. Therefore, the degradation of entire total RNA is evidence that GDH isoenzymes synthesize an equally complex mix of RNA enzyme to control the abundance of entire transcriptome. The degradation of total RNA by nongenetic code-based RNA is a crowding (mass action) phenomenal chemical reaction whereby many different nongenetic code-based RNA enzyme sequences attack their respective homologous genetic code-based RNAs simultaneously and non-synchronously [10]. All the GDH-synthesized RNA enzymes (Table 2) constitute the new phenomenal paradigm in cowpea biology, growth and dry grain yield.

Cowpea GDH isoenzymes synthesized a complicated mix of RNAs (Table 2) that are homologous to many mRNAs encoding regulatory enzymes that spread over a network of critically indispensable biochemical functions. All the fragments of cowpea GDH-synthesized RNA enzymes share plus/plus or plus/minus sequence homologies; therefore, there is a complex and interlocking network organization of the chemical functions of the fragments to create the mosaic GDH biochemical pathway that integrates/discriminates, at the total RNA level, all the biochemical, physiological, metabolic, and genetic processes.

The RNA enzymes are deeply entrenched in the global integration of cowpea photosynthesis at the total RNA level that 1) influence the concentrations of ribulose-bisphosphate and $\mathrm{CO}_{2}$ (ribulose-bisphosphate carboxylase/oxygenase); 2) the light-driven cyclic electron transfer from plastocyanin to ferredoxin in Photosystem I (apoprotein A2 P700); 3) oxygenic photosynthesis of Photosystem II (NADH plastoquinone oxidoreductase); 4) middle lamellar biochemical organization of chloroplasts (digalactosyldiacylglycerol synthase); 5) biochemical storage of photosynthate starch, a food product for which cowpea was domesticated (starch synthase); 6) balancing of substrate level ATP and NADPH production in photosynthesis with their utilization in the Calvin-Benson cycle (cytochrome B6 complex); 7) equilibration of $\mathrm{CO}_{2}$ and bicarbonate ion concentrations and making them readily available in photosynthesis (carbonic anhydrase). The GDH biochemical pathway exerted a tentacle-like hold across the entirety of the photosynthetic physiology, and of cowpea growth, development, and yield (Table 2).

Cowpea GDH biochemical pathway also exerted a strangle-hold on saccharide biochemistry and glycolysis because GDH synthesized RNA enzyme \#10 (Table 2) shared sequence homology with the mRNA encoding fructokinase. In green leaves, sucrose is the main end product of photosynthesis. The sucrose is converted to fructose and glucose by invertases. The resulting fructose is phosphorylated by fructokinase to fructose-6-phosphate, whereas the resulting glucose is phosphorylated by hexokinase to hexose-6-phosphate for entrance into glycolysis. Fructokinase is central in saccharide biochemistry regulating fructose flux in 
cells and homeostasis [69]. By regulating the abundance of the mRNAs encoding fructokinase and starch synthase (GDH-synthesized RNA nos. 4, 7, 9, 19), GDH biochemical pathway maintained a unique and an important chemical balance between photosynthate accumulation, saccharide metabolism, and glycolysis, and of cowpea growth and grain yield (Table 1 , and Table 2 ).

The GDH biochemical pathways control the abundance of the mRNA encoding the globulin (vicilin), the main storage protein for which cowpea is globally acclaimed as the source of affordable dietary plant protein. When the total protein content of cowpea seeds was low as in unfertilized control cowpea, it suggested that GDH synthesized the RNA enzyme fragment \#5 (Table 2) that partially degraded some of the mRNA encoding the vicilin [9]. Therefore, GDH through synthesis of RNA maintains a biochemical equilibrium between the plants' exterior environment and the interior biochemical, metabolic, physiological environment, as reflected by cowpea dry grain yield (Table 1).

Cowpeas are hardy plants being drought resistant and able to thrive under the inversion by fungi and insects. The mRNAs encoding the proteins: dehydrin, delta-1-pyrroline-5-carboxylase synthase, and drought inducible protein that protect cowpeas from dehydration are among the substrates of the GDH-synthesized RNA. Drought is the most debilitating environmental stress factor that decreases crop growth and harvest yield. When cowpeas were treated with regular fertilizers, their GDHs synthesized one or more of the RNA enzyme fragment nos. 2, $10,14,17$ (Table 2) that partially degraded the mRNAs encoding the drought protective enzymes, resulting to more than 50\% decreases in dry seed yields (Table 1). Cowpea machinery for resistance to stress extends to the degradation of the mRNA encoding triacylglycerol lipase. Cowpea GDH-synthesized RNA \#16 shared sequence homology with the mRNA encoding triacylglycerol lipase (Table 2). While cowpea does not produce a lot of triglycerides, their accumulation provides a mechanism by which the crop copes with abiotic stress. Different types of abiotic stress induce lipid remodeling through the action of lipases, which results in various alterations in membrane lipid composition. This response induces the formation of toxic lipid intermediates that cause membrane damage or cell death. However, triacylglycerols under stress conditions function as a means of sequestering the toxic lipid intermediates. Moreover, the lipid droplets in which triacylglycerol is enclosed also function as a subcellular factory to provide binding sites and substrates for the biosynthesis of bioactive compounds that protect against insects and fungi [70]. Therefore, cowpea grain yield (Table 1) was also controlled by GDH-synthesized RNA nos. 2, 10, 14, and 17.

GDH isoenzymes synthesized RNA enzymes that shared sequence homologies with mRNAs encoding key enzymes (isoflavone synthase, apyrase, extensin, ferric leghemoglobin reductase, and lectin) in the rhizobium-cowpea nodulation machinery. Fixing of atmospheric nitrogen and converting it to organic nitrogen is a special attribute of leguminous plants, enabling them to thrive on infertile soils. Treatment of cowpea with inappropriate mineral nutrients induced GDH 
to synthesize one or more of the RNA enzyme fragment nos. 5, 8, 9, 10, 11, 12, 15 , and 17 (Table 2) that are homologous to the mRNAs encoding the cowpea-rhizobium specific enzymes, with resultant decreases in total amino acid contents and grain yield (Table 1 ).

GDH isoenzymes synthesized RNA enzyme \#5, (Table 2) that shared sequence homology with the mRNAs encoding the peroxidases. Peroxidases participate in cell wall stiffening reactions by synthesizing lignin [71] [72], whose carbon content (soil organic carbon) is associated with the improvement of the aggregation, chemical and agricultural properties of the soil. This is another mechanism by which cowpea cover crop improves soil chemistry. When cowpea was treated with inappropriate fertilizer, the soil organic carbon content decreased five-fold suggesting that the GDH isoenzymes synthesized RNA enzyme \#5 (Table 2) that destroyed the mRNA encoding the peroxidases [73]. Therefore, inappropriate fertilization that caused decreases of soil organic carbon contents [7] led to decreases in cowpea dry grain yield (Table 1).

Cowpea GDH isoenzymes repeatedly synthesized numerous RNA enzyme fragments (Table 2: nos. 1, 2, 5, 8, 9, 19) that were homologous to the mRNAs encoding the enzymes: phosphoribosyl pyrophosphate amidotransferase, formylglycinamide ribonucleotide amidotransferase, glycinamide ribonucleotide synthase, aminoimidazolecarboximide ribonucleotide transformylase/inosine monophosphate cyclohydrolase, amidoimidazole ribonucleotide carboxylase of purine and pyrimidine nucleotides, histidine, tryptophan, NADP, FAD, NAD, cytokinin, and purine alkaloid biosynthesis. Biosynthesis of purine nucleotides, xanthosine monophosphate, AMP, and GMP require a lot of metabolic intermediates. AMP and GMP are the building blocks of DNA and RNA; and in addition, AMP is the precursor for the cytokinin group of plant growth regulators and a number of important coenzymes. GTP and ATP participate in the energy metabolism of the cell. Although there are a number of routes that can generate the purine bases from IMP, in legume nodules, the preferred route is through IMP dehydrogenase. Both xanthosine and xanthine serve as precursors for the purine alkaloids (theobromine and caffeine) and their further oxidation yields the ureides, allantoin and allantoic acid [59] all of which exert further metabolic demand on cowpeas especially when it is cultivated on infertile soils. These extensive metabolite demands [51] of purine, pyrimidine pathways may explain why the GDH biochemical pathway steps-in to minimize the wastage of the limited resources of cowpea in the synthesis of DNA, RNA, and cofactors that the crop may not need for its survival during its short growing season in the arid Sahel of Sub-Sahara. Therefore, wild-type cowpeas in the Sub-Sahara grow slowly, mature abruptly, and the seed yield is very low. [2] [8]. Wherefore, GDH through synthesis of RNA maintains a biochemical equilibrium between the cowpea exterior environment and the interior biochemical, metabolic, and physiological environment, all of which reflect on the dry grain yield (Table 1 ).

The water-tight control of cowpea physio-chemical pathways by environmen- 
tal conditions and the GDH-synthesized RNA extends to the biosynthesis of amino acids by phosphoenol-pyruvate carboxylase (PEPCase) whose mRNA shared sequence homology with GDH-synthesized RNA \#16 (Table 2). PEPCase recycles $\mathrm{CO}_{2}$ released during photorespiration thus minimizing carbon losses and enhancing carbon economy in higher plants [74]. Pyruvate kinase could convert phosphoenolpyruvate to pyruvate which is the starting intermediate for the biosynthesis of valine, leucine, and alanine. Oxaloacetate is the starting intermediate in the biosynthesis of isoleucine, threonine, lysine, and methionine [15]. Because the relative concentrations of phosphoenolpyruvate and oxaloacetate depend on PEPCase activity, the abundance of the mRNA encoding the enzyme is important in the molecular integration of amino acid biosynthesis. Therefore, GDH-synthesized RNA \#16 functions as a gigantic traffic light, controlling at the molecular level, the biosynthesis and flux of all the essential amino acids (isoleucine, threonine, lysine, methionine, phenylalanine, tryptophane, valine, leucine) in cowpea as in peanut also [15]. Wherefore, GDH through synthesis of RNA maintains a chemical equilibrium between the plants' exterior environment and the interior biochemical, metabolic, and physiological environment, all of which reflect on the dry grain yield (Table 1 ).

GDH isoenzymes repeatedly synthesized RNA fragments 5, 8, 11, and 17 (Figure 3, and Table 2) that shared sequence homology with the mRNA encoding isoflavone synthase. Since isoflavone synthase regulates crop growth and yield [54], it is probably among the traits that determine the earliness of cowpea maturity (Table 1). The cowpea improvement programs [2] did not identify the genetic traits controlling the earliness of grain maturity.

Cowpea GDH pathway extends to phenylpropanoid biochemical pathways. GDH-synthesized RNA \#12 (Table 2) shared sequence homology with the mRNAs encoding 4-coumarate: CoA ligase family that catalyze the activation of 4-coumarate and a few related substrates to the respective CoA esters and thus channels the product phenylalanine into the general phenylpropanoid biochemistry. These phenylpropanoid branch pathways generate various classes of natural products [15] [16] [75] with important functions in plant development and environmental interactions, including lignin for structural support, flavones and flavonols for UV protection; anthocyanins, isoflavones for growth and seed maturation; chalcones and aurones as pigments for the attraction of pollinators and seed distributors; and furanocoumarins as phytoalexins for pest/pathogen defense [76]. Therefore, GDH-synthesized RNA \#12 could have participated in the control of cowpea grain yield.

The regulation of cowpea phenylpropanoid pathway by GDH-synthesized RNA enzyme started at the phenylalanine ammonia lyase (PAL) entry point because GDH repeatedly synthesized RNA fragment nos. 1, 2, 4, 5, 10, 18, and 19 (Table 2) that shared sequence homology with the mRNA encoding PAL. This repeated synthesis of the RNA fragments homologous to PAL mRNA assures that at least one of them will be synthesized to downregulate the phenylpropa- 
noid pathway no matter how variable the soil mineral concentration and composition were. Many natural products including phenolic compounds, organic acids, glycosides, antioxidants, tannins etc are synthesized by the phenylpropanoid pathway. Most of the natural products are protective to cowpea, but a few (glycosides, and antinutrients) are toxic, causing immunomodulatory effects [77], and the flavonoid glycosides inhibit low density lipoprotein (LDL) oxidation when raw cowpea is consumed. It is possible to manipulate the GDH biochemical pathway so as to knockout the synthesis of the glycosides and antinutrients and thereby expand the global acceptability of cowpea products as food and snacks.

\subsection{Optimization of Cowpea Dry Grain Yield by Stoichiometric Mixes of Mineral Salts}

All the stoichiometric mixes of mineral salts outperformed the control cowpea and the cowpeas cultivated by USA farmers (Table 1) in the dry grain yields they induced. The most outstanding performance was the doubling of grain yield by the $\mathrm{K}+\mathrm{K}+\mathrm{K}$ treatment compared with the control cowpea, and the tripling of grain yield compared with USA farmers' yields (Table 1). Limited resource and subsistence farmers can now increase, double, optimize, or maximize their grain yields of cowpeas at little to no cost. The quantities of stoichiometric mineral salts needed are miniscule and far less expensive than commercial fertilizers.

Mineral salts and environmental factors stimulate plant GDH to synthesize nongenetic code-based RNA which then degrade their homologous mRNAs in order to tailor the plant's biochemical and physiological processes to be at equilibrium with the available external resources for sustaining the growth and survival of the plant. Plants degrade superfluous mRNA in order to minimize wastage of metabolic energy in the synthesis of proteins that the plant might not need to survive in the prevailing external environment. The mRNAs (Table 2) include those that may be degraded when adverse environmental conditions induce the cowpea GDH to synthesize RNA enzymes. The cyclical synthesis of plus-RNA and minus-RNA by GDH is therefore an economic tactical plan in biochemistry for the selection of superfluous mRNA that would be degraded for assuring the survival of cowpea growing under unfavorable environmental conditions. The plus-RNA synthesis in the amination direction, and minus-RNA synthesis in the deamination direction also guarantee the availability of complex mix of nongenetic code-based RNA enzymes that would match the nucleotide sequences of the superfluous mRNAs to be degraded. Cowpeas normally thrive in harsh environments [78]. The degradation of superfluous mRNAs by GDH-synthesized RNA is not always a complete chemical reaction because of the multiplicity of the environmental factors that simultaneously induce the enzyme to synthesize RNAs. Statistical permutation of all the biochemical pathways that have been partially and completely down-regulated gives the picture of the response of the crop growth and yield to the prevalent environmental factors 
[11] [15] [16]. Treatment of cowpea with $\mathrm{K}+\mathrm{K}+\mathrm{K}$ stoichiometric $\mathrm{KCl}$ solution silenced some of the yield-related mRNAs (Table 2) resulting to the increase of gain yield to $7598 \mathrm{~kg}$ from $3644 \mathrm{~kg} \cdot \mathrm{ha}^{-1}$ in the control cowpea. The resultant permuted biochemical pathway in the $\mathrm{K}+\mathrm{K}+\mathrm{K}$-treated cowpea was therefore different from that of the control cowpea. Accordingly, each stoichiometric mix of mineral salts (Table 1) induced a unique permutation of cowpea biochemical pathways because the resultant early grain harvest, second grain harvest, and total grain yields were unique from one stoichiometric mineral salts to another. Each stoichiometric mix (Table 1) produced a unique optimally yielding biochemical variant of purple hull cowpea. Thus, limited resources farmers who produce cowpea dry grains for feeding their families and for farm income can now apply the stoichiometric mineral salt mixes to produce the grain yields to meet their domestic needs, without surplus harvests that are often wasted due to lack of postharvest storage infrastructures. The stoichiometric mixes of mineral salts and the GDH-synthesized RNA enzymes that they stimulated (Table 1, and Table 2) revealed the multiplicity of molecular targets that regulate cowpea mineral nutrient biochemistry and dry grain yield. Many studies on cowpea mineral ion biochemistry did not uncover any molecular target of the actions of the mineral ions [79].

Many cowpea breeding programs [2] [6] have produced cultivars that are pest and drought resistant which mature early thereby potentially contributing to all-season food availability and food security. But the dry grain yields of the genetically improved lines remained very low in farmers' plots especially in Sub-Saharan Africa [2] [8]. Cowpea GDH biochemical pathways (Table 2) suggested that relieving the stranglehold exerted on the lignocellulosic, photosynthetic, amino acid, nodulation, saccharide, storage protein, purine/pyrimidine etc. metabolic/physiological pathways might permit the dry grain harvest and nutritious yield to increase, double, and even to be maximized without cultivating more land area. The stoichiometric mineral salt mixes (Figure 1, Figure 2, Table 1, and Table 2) have demonstrated their abilities to alter the distribution patterns of GDH isoenzymes, the abilities of the isoenzymes to change the structural complexities of the nongenetic code-based plus-RNA and minus-RNA enzymes (Figure 3, and Figure 4) they synthesize, and for the cowpea grain yield to be optimized. The early maturing dry grain harvests were not significantly improved compared with that of the control (Table 1), but the slow maturing grain harvests were significantly higher in the treated cowpea compared with the control cowpea. The slow maturing harvest of the $\mathrm{K}+\mathrm{K}+\mathrm{K}$-treated cowpea was a whopping $300 \%$ higher than that of the control cowpea (Table 1).

The subunit polypeptide compositions of GDH hexamers are similar but not identical (Figure 1). Similarly, most of the mineral salt compositions of stoichiometric mixes (Table 1) are similar but not identical. Total dry grain yields (Table 1) of cowpea that were stimulated by similar GDH isoenzyme populations, and similar stoichiometric mixes of mineral salts were biochemically different. These 
were the biochemical dynamics that were embedded in the GDH pathways (Table 2) that discriminated, integrated, optimized, enhanced, and maximized cowpea dry grain yield molecular biology.

The stoichiometric mixes of mineral salts displayed mineral ion synergism on cowpea grain yield. $\mathrm{K}+\mathrm{K}+\mathrm{K}$ stoichiometric $\mathrm{KCl}$ treatment increased cowpea grain yield by $31 \%$ compared with $\mathrm{K}+\mathrm{K}$ treatment which in turn increased the grain yield by $19 \%$ compared with $K$ treatment (Table 1). Similarly, $K+K+S$ treatment increased the grain yield by $32 \%$ compared with the $\mathrm{K}+\mathrm{S}$ treatment (Table 1). It was also notable that regular fertilizer was not as active as many stoichiometric mixes of mineral salts in the stimulation of the RNA synthetic activity of GDH including the increase of grain yield (Table 1). The control registered the lowest grain yield in spite of the nitrogen fixing ability of cowpea. This suggested that the nitrogen fixing apparatus needed the support of stoichiometric mixes of mineral salts in order for cowpea grain yield to be maximized, doubled, and optimized (Table 1, Table 2; Figure 4). Wherefore, the GDH biotechnology for doubling and maximizing crop nutritious yields [11] [12] [15] [16] [75] [80] is fail-proof, affordable, simple, and limited resources famer friendly because the biotechnology allows subsistence farmer to plan in advance to produce only what she needs to assure her family's food security, and that she can sell in the village/local market, thus avoiding wastage of man-hour inputs in the production of surplus harvests that she cannot warehouse [8].

\subsection{Biotechnological Applications}

Several technologically valuable biochemical processes in plant systems with potential for conversion to industrial application still remain as inexplicable phenomena. The inability to remove camphor from Phyla dulcis plant extracts by deployment of camphor-degrading bacteria [82]; to couple terpene synthase production of bisabolol to cytochrome $\mathrm{P} 450$ oxidation of the bisabolol and to sweet sesquiterpene hernandulcin in engineered yeast [83]; to harness electricity from photosynthetic thylakoid membrane [84]; to extend nitrogen fixation from legumes to monocots [85] are notable biochemical examples because of the benefits that could be derived by mankind. The stoichiometric mixes of mineral salt treatment of crop have demonstrated their abilities to alter the distribution patterns of GDH isoenzymes, the abilities of the isoenzymes to change the structural complexities of the nongenetic code-based plus-RNA and minus-RNA enzymes they synthesize, and for the biochemical pathways of the crop to be altered, thereby providing a new approach for eliminating any biochemical intermediate(s) at will, or for increasing any biochemical end-product(s) at will without engineering the crop and without cultivating more landscape [10]-[17] [21] [67] [75]. The regulation of the dry grain yield of cowpea, a nutritious leguminous food crop of the world, was an inexplicable challenge in biology [3] [4] [5] [6] [78] [79]. But the chemistry of the oxidoreductase cyclical synthesis of plus-RNA in the amination, and minus-RNA in the deamination direction by 
GDH illuminated the hitherto inexplicable phenomenon in molecular biology (Figures 1-4, Table 2), leading to the enhancement, optimization, and maximization of the dry grain yield from $1984 \mathrm{~kg} \cdot \mathrm{ha}^{-1}$ to $7598 \mathrm{~kg} \cdot \mathrm{ha}^{-1}$ (Table 1) simply by treatment of cowpea in field plots with stoichiometric mixes of mineral salts solutions. The technology is friendly to limited resources farmers who cultivate the crop.

\section{Acknowledgements}

The research program on cowpea was funded through research grants made available to Prairie View A \& M University by USDA NIFA.

\section{Conflicts of Interest}

The authors declare no financial conflicts of interest regarding the contents of this publication.

\section{References}

[1] Rawal, V. and Navarro, D.K. (2019) The Global Economy of Pulses. Food and Agriculture Organization of the United Nations, Rome.

[2] IITA Annual Report (1984) International Institute of Tropical Agriculture: Grain Legume Improvement Program. 64-117.

[3] Munoz-Amatriain, M., Mirebrahim, H., Xu, P., Wanamaker, S., Lou, M., et al. (2017) Genome Resource for Climate-Resilient Cowpea, an Essential Crop for Food Security. The Plant Journal, 89, 1042-1054. https://doi.org/10.1111/tpj.13404

[4] Kebede, E. and Bekeko, Z. (2020) Expounding the Production and Importance of Cowpea (Vigna unguiculata (L.) Walp.) in Ethiopia. Cogent Food \& Agriculture, 6, Article ID: 1769805. https://doi.org/10.1080/23311932.2020.1769805

[5] Horn, L.N. and Shimelis, H. (2020) Production Constraints and Breeding Approaches for Cowpea Improvement for Drought Prone Agro-Ecologies in Sub-Saharan Africa. Annals of Agricultural Sciences, 65, 83-91. https://doi.org/10.1016/j.aoas.2020.03.002

[6] Ehlers, J.D., Fery, R.I. and Hall, A.E. (2002) Cowpea Breeding in the USA: New Varieties and Improved Germplasm. In: Fatokun, C.A., Tarawali, S.A., Singh, B.B., Kormawa, P.M. and Tamo, M., Eds., Challenges and Opportunities for Enhancing Sustainable Cowpea Production, IITA Publisher, Ibadan, 62-77.

[7] Agboola, A.A. (1978) Influence of Soil Organic Matter on Cowpea's Response to N Fertilizer. Agronomy Journal, 70, 25-28. https://doi.org/10.2134/agronj1978.00021962007000010007x

[8] Bingen, R.J., Hall, A.E. and Ndoye, M. (1988) California Cowpea and Food Policy in Senegal. World Development, 16, 857-865. https://doi.org/10.1016/0305-750X(88)90018-6

[9] Osuji, G.O. and Madu, W.C. (2015) Glutamate Dehydrogenase. In: D’Mello, J.P.F., Ed., Edition: Amino Acids in Higher Plants, CABI Publishers, Wallingford, Boston, 1-29. https://doi.org/10.1079/9781780642635.0001

[10] Osuji, G.O., Madu, W.C. and Johnson, P.M. (2019) Total RNA Degradation in Vitro and in Vivo by Glutamate Dehydrogenase-Synthesized RNA Enzyme: Biotechnological Applications. Advances in Bioscience and Biotechnology, 10, 59-85. 
https://doi.org/10.4236/abb.2019.104005

[11] Osuji, G.O., Brown, T.K., South, S.M., Duncan, J.C. and Johnson, D. (2011) Doubling of Crop Yield through Permutation of Metabolic Pathways. Advances Bioscience Biotechnology, 2, 364-379. https://doi.org/10.4236/abb.2011.25054

[12] Osuji, G.O., Brown, T.K. and South, S.M. (2010) Optimized Fat and Cellulosic Biomass Accumulation in Peanut through Biotechnology. International Journal of Biotechnology and Biochemistry, 6, 455-476.

[13] Osuji, G.O., Reyes, J.C. and Mangaroo, A.S. (1998) Glutamate Dehydrogenase Isomerization: A Simple Method for Diagnosing Nitrogen, Phosphorus, and Potassium Sufficiency in Maize (Zea mays L.). Journal of Agricultural and Food Chemistry, 46, 2395-2401. https://doi.org/10.1021/jf971065x

[14] Osuji, G.O. and Madu, W.C. (1997) Regulation of Sweetpotato Growth and Differentiation by Glutamate Dehydrogenase. Canadian Journal of Botany, 75, 1070-1078. https://doi.org/10.1139/b97-118

[15] Osuji, G.O., Duffus, E., Johnson, P., Woldesenbet, S., Weerasooriya, A., et al. (2015) Enhancement of the Essential Amino Acid Composition of Food Crop Proteins through Biotechnology. American Journal of Plant Sciences, 6, 3091-3108. https://doi.org/10.4236/ajps.2015.619302

[16] Osuji, G.O., Johnson, P., Duffus, E., Woldesenbet, S. and Kirven, J.M. (2017) Horticultural Production of Ultra-High Resveratrol Peanut. Agricultural Sciences, 8, Article ID: 80053. https://doi.org/10.4236/as.2017.810086

[17] Osuji, G.O., Brown, T.K. and South, S.M. (2008) Discovery of the RNA Synthetic Activity of Glutamate Dehydrogenase and Its Application in Drug Metabolism Research. The Open Drug Metabolism Journal, 2, 1-13. https://doi.org/10.2174/1874073100802010001

[18] Osuji, G.O., Brown, T.K. and South, S.M. (2009) Nucleotide-Dependent Reprogramming of mRNAs Encoding Acetyl Coenzyme A Carboxylase and Lipoxygenase in Relation to the Fat Contents of Peanut. Journal of Botany, 2009, Article ID: 278324. https://doi.org/10.1155/2009/278324

[19] Osuji, G.O., Braithwaite, C., Pointer, R. and Reyes, J. (1999) Pesticide Inactivation of Peanut Glutamate Dehydrogenase: Biochemical Basis of the Enzyme's Isomerization. Journal of Agricultural and Food Chemistry, 47, 3345-3351. https://doi.org/10.1021/jf980531v

[20] Osuji, G.O. and Brown, T. (2007) Role of the RNAs Synthesized by Glutamate Dehydrogenase in the Coordinate Regulation of Metabolic Processes. ICFAI Journal of Biotechnology, 1, 37-48.

[21] Osuji, G.O. and Johnson, P.M. (2018) Structural Properties of the RNA Synthesized by Glutamate Dehydrogenase for the Degradation of Total RNA. Advances in Enzyme Research, 6, 29-52. https://doi.org/10.4236/aer.2018.63004

[22] Osuji, G.O. and Madu, W.C. (1997) Regulation of Peanut Glutamate Dehydrogenase by Methionine Sulphoximine. Phytochemistry, 46, 817-825. https://doi.org/10.1016/S0031-9422(97)00395-6

[23] Osuji, G.O. and Madu, W.C. (1995) Ammonium Ion-Dependent Isomerization of Glutamate Dehydrogenase in Relation to Glutamate Synthesis in Maize. Phytochemistry, 39, 495-503. https://doi.org/10.1016/0031-9422(94)00976-Z

[24] Loyola-Vargas, V.M. and De Jimenez, E.S. (1984) Differential Role of Glutamate Dehydrogenase in Nitrogen Metabolism of Maize Tissues. Plant Physiology, 76, 536-540. https://doi.org/10.1104/pp.76.2.536

[25] Osuji, G.O., Konan, J. and M’Mbijjewe, G. (2004) RNA Synthetic Activity of Glu- 
tamate Dehydrogenase. Applied Biochemistry and Biotechnology, 119, 209-228. https://doi.org/10.1007/s12010-004-0003-Z

[26] Osuji, G.O., Braithwaite, C., Fordjour, K., Madu, W.C., Beyene, A., Roberts, P.S and Wright, V. (2003) Purification of Glutamate Dehydrogenase Isoenzymes and Characterization of Their Substrate Specificities. Preparative Biochemistry and Biotechnology, 33, 13-28. https://doi.org/10.1081/PB-120018366

[27] Osuji, G.O. and Madu, W.C. (2012) Using the RNA Synthetic Activity of Glutamate Dehydrogenase to Illuminate the Natural Role of the Enzyme. Advances in Biological Chemistry, 2, 379-389. https://doi.org/10.4236/abc.2012.24047

[28] Grierson, D., Slater, J. and Tucker, G.A. (1985) The Appearance of Polygalacturonase mRNA in Tomatoes. Planta, 163, 263-271. https://doi.org/10.1007/BF00393517

[29] Osuji, G.O., Brown, T.K., South, S.M., Duncan, J.C., Johnson, D. and Hyllam, S. (2012) Molecular Adaptation of Peanut Metabolic Pathways to Wide Variation of Mineral Ion Composition and Concentration. American Journal of Plant Sciences, 3, 33-50. https://doi.org/10.4236/ajps.2012.31003

[30] Miyashita, Y. and Good, A.G. (2008) NADH-Dependent Glutamate Dehydrogenase Is Essential for the Survival of $A$. thaliana during Dark-Induced Carbon Starvation. Journal of Experimental Botany, 59, 667-680. https://doi.org/10.1093/jxb/erm340

[31] Lee, W., Shin, S., Cho, S.S. and Park, J. (1999) Purification and Characterization of Glutamate Dehydrogenase as Another Isoprotein Binding to the Membrane of Rough Endoplasmic Reticulum. Journal of Cellular Biochemistry, 76, 244-253. https://doi.org/10.1002/(SICI)1097-4644(20000201)76:2<244::AID-JCB8>3.0.CO;2$\underline{\mathrm{K}}$

[32] McCarthy, A.D., Walker, J.M. and Tipton, K.F. (1980) Purification of Glutamate Dehydrogenase from Ox Brain and Liver. Evidence That Commercially Available Preparations of the Enzyme from Ox Liver Have Suffered Proteolytic Cleavage. Biochemical Journal, 191, 605-611. https://doi.org/10.1042/bj1910605

[33] Brodelius, P.E. and Kaplan, K.O. (1979) Studies on Bovine Liver Glutamate Dehydrogenase by Analytical Affinity Chromatography on Immobilized AMP Analogs. Archives Biochemistry and Biophysics, 194, 449-456.

https://doi.org/10.1016/0003-9861(79)90639-8

[34] Godinot, C., Julliard, J.H. and Gautheron, D.C. (1974) A Rapid and Efficient New Method of Purification of Glutamate Dehydrogenase by Affinity Chromatography on GTP-Sepharose. Analytical Biochemistry, 61, 264-270. https://doi.org/10.1016/0003-2697(74)90353-4

[35] Chandrasekhar, K. and Malath, R. (2003) Non Watson Crick Base Pairs Might Stabilize RNA Structural Motifs in Ribosomes-A Comparative Study of Group-1 Intron Structures. Journal of Bioscience, 28, 547-555.

https://doi.org/10.1007/BF02703330

[36] Ifuku, K., Endo, T., Shikanai, T. and Aro, E. (2011) Structure of the Chloroplast NADH Dehydrogenase-Like Complex: Nomenclature for Nuclear-Encoded Subunits. Plant and Cell Physiology, 52, 1560-1568. https://doi.org/10.1093/pcp/pcr098

[37] Roje, S., Janave, M.T., Ziemak, M.J. and Hanson, A.D. (2002) Cloning and Characterization of Mitochondrial 5-Formyltetrahydrofolate Cycloligase from Higher Plants. Journal of Biological Chemistry, 277, 42748-42754.

https://doi.org/10.1074/jbc.M205632200

[38] Hove-Jensen, B., Kasper, R., Andersen, K.R., Kilstrup, M., Martinussen, J., Switzer, R.L. and Willemoësd, M. (2017) Phosphoribosyl Diphosphate (PRPP): Biosynthesis, Enzymology, Utilization, and Metabolic Significance. Microbiology and Molecular 
Biology Reviews, 81, e00040-16. https://doi.org/10.1128/MMBR.00040-16

[39] Hyun, M.W., Yun, Y.H., Kim, J.Y. and Kim, S.H. (2011) Fungal and Plant Phenylalanine Ammonia-Lyase. Mycobiology, 39, 257-265. https://doi.org/10.5941/MYCO.2011.39.4.257

[40] Zhang, Y., Morar, M. and Ealick, S.E. (2008) Structural Biology of the Purine Biosynthetic Pathway. Cellular and Molecular Life Sciences, 65, 3699-3724. https://doi.org/10.1007/s00018-008-8295-8

[41] Juszczuk, I.M. and Rychter, A.M. (2003) Alternative Oxidase in Higher Plants. Acta Biochimica Polonica, 50, 1257-1271. https://doi.org/10.18388/abp.2003 3649

[42] Ismail, A.M., Hall, A.E. and Close, T.J. (1999) Allelic Variation of a Dehydrin Gene Co-Segregates with Chilling Tolerance during Seedling Emergence. Proceedings of the National Academy of Sciences of the United States of America, 96, 13566-13570. https://doi.org/10.1073/pnas.96.23.13566

[43] Fujii, S., Kobayashi, K., Nagata, N., Masuda, T. and Wada, H. (2018) Digalactosyldiacylglycerol Is Essential for Organization of the Membrane Structure in Etioplasts. Plant Physiology, 177, 1487-1497. https://doi.org/10.1104/pp.18.00227

[44] Endo, K., Kobayashi, K. and Wada, H. (2016) Sulfoquinovosyldiacylglycerol Has an Essential Role in Thermosynechococcus Elongatus BP-1 under Phosphate Deficient Conditions. Plant and Cell Physiology, 57, 2461-2471.

https://doi.org/10.1093/pcp/pcw159

[45] Gong, B., Sun, S., Yan, Y., Jing, X. and Shi, Q. (2018) Glutathione Metabolism and Its Function in Higher Plants Adapting to Stress. In: Gupta, D.K., Palma, J.M. and Corpas, F.J., Eds., Antioxidants and Antioxidant Enzymes in Higher Plants, Springer, Berlin, 181-205. https://doi.org/10.1007/978-3-319-75088-0 9

[46] Tetlow, I.J., Morell, M.K. and Emes, M.J. (2004) Recent Developments in Understanding the Regulation of Starch Metabolism in Higher Plants. Journal of Experimental Botany, 55, 2131-2145. https://doi.org/10.1093/jxb/erh248

[47] Schöttler, M.A., Tóth, S.Z., Boulouis, A. and Kahlau, S. (2015) Photosynthetic Complex Stoichiometry Dynamics in Higher Plants: Biogenesis, Function, and Turnover of ATP Synthase and the Cytochrome b6f Complex. Journal of Experimental Botany, 66, 2373-2400. https://doi.org/10.1093/jxb/eru495

[48] Caverzan, A., Passaia, G., Barcellos, S., Carolina, R., Ribeiro, W., Lazzarotto, F. and Margis-Pinheiro, M. (2012) Plant Responses to Stresses: Role of Ascorbate Peroxidase in the Antioxidant Protection. Genetics and Molecular Biology, 35, 1011-1019. https://doi.org/10.1590/S1415-47572012000600016

[49] Curtis, T.Y., Bo, V., Tucker, A. and Halford, N.G. (2018) Construction of a Network Describing Asparagine Metabolism in Plants and Its Application to the Identification of Genes Affecting Asparagine Metabolism in Wheat under Drought and Nutritional Stress. Food Energy Security, 7, e00126. https://doi.org/10.1002/fes3.126

[50] Mousavi, A. and Hotta, Y. (2005) Glycine-Rich Proteins: A Class of Novel Proteins. Applied Biochemistry and Biotechnology, 120, 169-174.

https://doi.org/10.1385/ABAB:120:3:169

[51] Boldt, R. and Zrenner, R. (2003) Purine Pyrimidine Biosynthesis in Higher Plants. Physiologia Plantarum, 117, 297-304. https://doi.org/10.1034/j.1399-3054.2003.00030.x

[52] Eichelmann, H. and Laisk, A. (1999) Ribulose-1,5-Bisphosphate Carboxylase or Oxygenase Content, Assimilatory Charge, and Mesophyll Conductance in Leaves. Plant Physiology, 119, 179-189. https://doi.org/10.1104/pp.119.1.179

[53] Marcus, J.P., Green, J.L., Goulter, K.C. and Manners, J.M. (1999) A Family of Anti- 
microbial Peptides Is Produced by Processing of a 7S Globulin Protein in Macadamia integrifolia Kernels. The Plant Journal, 19, 699-710. https://doi.org/10.1046/j.1365-313x.1999.00569.x

[54] Sugiyama, A., Yamazaki, Y., Hamamoto, S., Takase, H. and Yazak, K. (2017) Synthesis and Secretion of Isoflavones by Field-Grown Soybean. Plant and Cell Physiology, 58, 1594-1600. https://doi.org/10.1093/pcp/pcx084

[55] Amann, A., Lezhneva, L., Wanner, G., Herrmann, R.G. and Meurer, J. (2004) ACCUMULATION of PHOTOSYSTEM ONE1, a Member of a Novel Gene Family, Is Required for Accumulation of [4Fe-4S] Cluster-Containing Chloroplast Complexes and Antenna Proteins. Plant Cell, 16, 3084-3097.

https://doi.org/10.1105/tpc.104.024935

[56] Simoes, I. and Faro, C. (2004) Structure and Function of Plant Aspartic Proteinases. European Journal of Biochemistry, 271, 2067-2075.

https://doi.org/10.1111/j.1432-1033.2004.04136.x

[57] Lo, S., Munoz-Amatriain, M., Boukar, O., Herniter, I., Cisse, N., et al. (2018) Identification of QTL Controlling Domestication Related Traits in Cowpea (Vigna unguiculata L. Walp). Scientific Reports, 8, Article No. 6261.

https://doi.org/10.1038/s41598-018-24349-4

[58] Tanaka, K., Nguyen, T.H. and Stacey, G. (2011) Enzymatic Role for Soybean Ecto-Apyrase in Nodulation. Plant Signaling and Behavior, 6, 1034-1036. https://doi.org/10.4161/psb.6.7.15601

[59] Smith, P.M.C. and Atkins, C.A. (2002) Purine Biosynthesis. Big in Cell Division, Even Bigger in Nitrogen Assimilation. Plant Physiology, 128, 793-802. https://doi.org/10.1104/pp.010912

[60] Iuchi, S., Yamaguchi-Shinozaki, K., Urao, T. and Shinozaki, K. (1996) Novel Drought-Inducible Genes in the Highly Drought-Tolerant Cowpea: Cloning of cDNA and Analysis of the Expression of the Corresponding Genes. Plant and Cell Physiology, 37, 1073-1080. https://doi.org/10.1093/oxfordjournals.pcp.a029056

[61] Becana, M. and Klucas, R.V. (1992) Oxidation and Reduction of Leghemoglobin in Root Nodules of Leguminous Plants. Plant Physiology, 98, 1217-1221.

https://doi.org/10.1104/pp.98.4.1217

[62] Coleman, J.R. (2000) Carbonic Anhydrase and Its Role in Photosynthesis. In: Leegood, R.C., Sharkey, T.D. and von Caemmerer, S., Eds., Photosynthesis: Physiology and Metabolism, Kluwer Academic Publishers, Dordrecht, 353-367.

https://doi.org/10.1007/0-306-48137-5 15

[63] Hu, C.A., Delauney, A.J. and Verma, D.P.S. (1992) A Bifunctional Enzyme (Delta 1-Pyrroline-5-carboxylate Synthetase) Catalyzes the First Two Steps in Proline Biosynthesis in Plants. Proceedings of the National Academy of Sciences of the United States of America, 89, 9354-9358. https://doi.org/10.1073/pnas.89.19.9354

[64] Lamport, D.T.A., Kieliszewski, M.J., Chen, Y. and Cannon, M.C. (2011) Role of the Extension Superfamily in Primary Cell Wall Architecture. Plant Physiology, 156, 11-19. https://doi.org/10.1104/pp.110.169011

[65] Arsenijevic-Maksimovic, I., Broughton, W.J. and Krouse, A. (1997) Rhizobia Modulate Root-Hair-Specific Expression of Extension Genes. Plant Microbe Interaction, 10, 95-101. https://doi.org/10.1094/MPMI.1997.10.1.95

[66] Sharon, N. (2007) Lectins: Carbohydrate-Specific Reagents and Biological Recognition Molecules. Journal of Biological Chemistry, 282, 2753-2764. https://doi.org/10.1007/978-1-4020-6953-6

[67] Osuji, G.O., Weerasooriya, A., Ampim, P.A.Y., Carson, L., Johnson, P., et al. (2015) 
Molecular Regulation of the Metabolic Pathways of the Medicinal Plants: Phyla dulcis. American Journal of Plant Sciences, 6, 1717-1726. https://doi.org/10.4236/ajps.2015.611171

[68] Iuchi, S., Kobavashi, M., Yamaguchi-Shinozaki, K. and Shinozaki, K. (2000) A Stress-Inducible Gene for 9-Cis-epoxycarotenoid Dioxygenase Involved in Abscisic Acid Biosynthesis under Water Stress in Drought-Tolerant Cowpeas. Plant Physiology, 123, 553-562. https://doi.org/10.1104/pp.123.2.553

[69] Yang, J., Zhu, L., Cui, W., Zhang, C., Li, D., et al. (2018) Increased Activity of MdFRK2, a High Affinity Fructokinase, Leads to Upregulation of Sorbitol Metabolism and Downregulation of Sucrose Metabolism in Apple Leaves. Horticulture Research, 5, 71. https://doi.org/10.1038/s41438-018-0099-x

[70] Lu, J., Xu, Y., Wang, J., Singer, S.D. and Chen, G. (2020) The Role of Triacylglycerol in Plant Stress Response. Plants, 9, 472. https://doi.org/10.3390/plants9040472

[71] Wight, J.P., Hons, F.M., South, S.M. and Osuji, G.O. (2012) Purification of Active Peroxidase Isoenzymes and Their Responses to Nitrogen Fertilization and Rotation of Biomass Sorghum. American Journal Plant Sciences, 3, 1422-1429. https://doi.org/10.4236/ajps.2012.310172

[72] Wight, J.P., Hons, F.M. and Osuji, G.O. (2014) Responses of Bioenergy Sorghum Cell Wall Metabolism to Agronomic Practices. Advances in Biological Chemistry, 4, 67-78. https://doi.org/10.4236/abc.2014.41010

[73] Osuji, G.O., Madu, W.C., Duffus, E., Johnson, P., et al. (2016) Regulated Lignin Structural Units and Soil Organic Carbon Contents by Cowpea Peroxidase. The Journal of Agricultural Science, 8, 12-22. https://doi.org/10.5539/jas.v8n9p12

[74] Singal, H.R. and Singh, R. (1986) Purification and Properties of Phosphoenolpyruvate Carboxylase from Immature Pods of Chickpea (Cecer arietium L). Plant Physiology, 80, 369-373. https://doi.org/10.1104/pp.80.2.369

[75] Osuji, G.O., Gao, M., Carson, L., Ampim, P., Weerasooriya, A., Johnson, P., Duffus, E., et al. (2017) Biotechnological Induction of Shikimate-Based Antioxidant Accumulation in Phyla dulcis. The Natural Products Journal, 7, 104-111.

https://doi.org/10.2174/2210315506666161017124440

[76] Hamberger, B. and Hahlbrock, K. (2004) The 4-Coumarate: CoA Ligase Gene Family in Arabidopsis thaliana Comprises One Rare, Sinapate-Activating and Three Commonly Occurring Isoenzymes. Proceedings National Academy Science USA, 101, 2209-2214. https://doi.org/10.1073/pnas.0307307101

[77] Kuete, V. (2013) 7-Phenylpropanoids and Related Compounds from the Medicinal Plants of Africa. In: Kuete, V., Ed., Medicinal Plants Research in Africa: Pharmacology and Chemistry, Elsevier Publisher, New York, 51-260. https://doi.org/10.1016/B978-0-12-405927-6.00007-2

[78] Kolawole, G.O., Tian, G. and Singh, B.B. (2000) Differential Response of Cowpea Lines to Application of P Fertilizer. In: Fatokun, C.A., Tarawali, S.A. and Singh, B.B., Eds., Challenges and Opportunities for Enhancing Sustainable Cowpea Production, IITA Publishers, Ibadan, 319-328.

[79] Fatokun, C.A., Tarawali, S.A. and Singh, B.B. (2000) Challenges and Opportunities for Enhancing Sustainable Cowpea Production. IITA Publication, Ibadan.

[80] Osuji, G.O., Mangaroo, A.S., Reyes, J., Bulgin, A. and Wright, V. (2003/4) Biomass Enhancement of Maize and Soybean in Response to Glutamate Dehydrogenase Isomerization. Biologia Plantarum, 47, 45-52.

https://doi.org/10.1023/A:1027324713682

[81] Abubakar, A., Ibrahim, H.A., Karaye, M.M., Yaro, M.A., Babuga, R.T. and Abdus- 
salam, B. (2018) Comparative Study of three Cowpea Variety against Different Soil Samples. Journal Chemical, Environmental and Biological Engineering, 2, 40-43.

[82] Eaton, R.W. and Sandusky, P. (2009) Biotransformation of 2-Methylisoborneol by Camphor-Degrading Bacteria. Applied Environmental Microbiology, 75, 583-588. https://doi.org/10.1128/AEM.02126-08

[83] Attia, M., Kim, S. and Ro, D. (2012) Molecular Cloning and Characterization of (+)-epi- $\alpha$-bisabolol Synthase, Catalyzing the First Step in the Biosynthesis of the Natural Sweetener, Hernandulcin, in Lippia dulcis. Archives of Biochemistry and Biophysics, 527, 37-44. https://doi.org/10.1016/j.abb.2012.07.010

[84] Calkins, J.O., Umasankar, Y., O’Neill, H. and Ramasamy, R.P. (2013) High Photo-Electrical Activity of Thylakoid-Carbon Nanotube Composites for Photosynthetic Energy Conversion. Energy \& Environmental Science, 6, 1891-1900. https://doi.org/10.1039/c3ee40634b

[85] Mus, F., Crook, M.B., Garcia, K., Costas, A.G., Geddes, B.A., Kouri, E.D., Paramasivan, P., et al. (2016) Synbiotic Nitrogen Fixation and the Challenges to Its Extension to Nonlegumes. Applied Environmental Microbiology, 82, 3698-3710. https://doi.org/10.1128/AEM.01055-16 